University of Louisville

ThinkIR: The University of Louisville's Institutional Repository

Electronic Theses and Dissertations

$12-2010$

\title{
Direct binding of parotid secretory protein to phosphatidylinositol phosphates.
}

Dipti Goyal 1984-

University of Louisville

Follow this and additional works at: https://ir.library.louisville.edu/etd

\section{Recommended Citation}

Goyal, Dipti 1984-, "Direct binding of parotid secretory protein to phosphatidylinositol phosphates." (2010). Electronic Theses and Dissertations. Paper 521.

https://doi.org/10.18297/etd/521

This Master's Thesis is brought to you for free and open access by ThinkIR: The University of Louisville's Institutional Repository. It has been accepted for inclusion in Electronic Theses and Dissertations by an authorized administrator of ThinkIR: The University of Louisville's Institutional Repository. This title appears here courtesy of the author, who has retained all other copyrights. For more information, please contact thinkir@louisville.edu. 


\title{
DIRECT BINDING OF PAROTID SECRETORY PROTEIN TO PHOSPHATIDYLINOSITOL PHOSPHATES
}

\author{
By \\ Dipti Goyal \\ B.D.S., PGIMS Rohtak (India), 2007
}

\begin{abstract}
A Thesis
Submitted to the Faculty of the

Graduate School of the University of Louisville

In Partial Fulfillment of the Requirements

For the Degree of
\end{abstract}

Master of Oral Biology

School of Dentistry

University of Louisville

Louisville, Kentucky

December 2010 
. 


\title{
DIRECT BINDING OF PAROTID SECRETORY PROTEIN TO PHOSPHATIDYLINOSITOL PHOSPHATES
}

\author{
By \\ Dipti Goyal \\ B.D.S., PGIMS Rohtak (India), 2007 \\ A Thesis Approved on \\ October 25, 2010 \\ by the following Thesis Committee: \\ Thesis Director
}




\section{ACKNOWLEDGEMENTS}

First of all, I would like to thank almighty god for blessing me the patience, strength and knowledge to complete this project. I owe my deepest gratitude to my mentor Dr.

Douglas S. Darling for his encouragement, guidance and support from the initial to the final level which enabled me to develop an understanding of the subject. His constant motivation, persistence and faith in me lead to the completion of this project. I would also like to thank my graduate committee members, Dr. Robert H. Staat and Dr. Evlambia Hasjishengallis for their constant support. I would like to thank my lab members Anne L. Carenbauer and Dr. Venkatesh G Srirangapatnam who taught me the basic techniques in the lab, and were always there to guide me.

I would like to thank my parents, my younger brother and my friends for their blessings, love and support and for having the confidence in me. Finally I would like to thank my better half Apurv Awasthi who stood by me always, and motivated me to work towards my goal. 


\title{
ABSTRACT \\ DIRECT BINDING OF PAROTID SECRETORY PROTEIN TO PHOSPHATIDYLINOSITOL PHOSPHATES
}

\author{
Dipti Goyal
}

October 25, 2010

BACKGROUND: Regulated secretion of protein by salivary and other exocrine glands requires correct trafficking of soluble cargo proteins into secretory vesicles. However, the molecular mechanism of sorting in the parotid salivary gland is unknown.

Phosphatidylinositol phospholipids, such as $\operatorname{Ptd} \operatorname{Ins}(3,4) \mathrm{P}_{2}$, are present in the membrane of secretory granules. We have shown that crude preparations of native Parotid Secretory Protein (PSP) bind PtdIns(3,4) $\mathrm{P}_{2}$; however, it is unclear whether this is due to a direct interaction.

HYPOTHESIS: We hypothesize that PSP directly binds $\mathrm{PtdIns}(3,4) \mathrm{P}_{2}$ with high affinity.

METHODS: Rat PSP cDNA with a C-terminal V5 tag was cloned into a glutathione-Stransferase (GST) expression vector. Conditions were optimized for expression and purification of protein. The affinity purified protein was cleaved from the GST tag using PreScission protease. To test for binding of PSP to PtdInsPs and quantify the binding affinity, the bacterially expressed proteins were used for lipid-overlay binding experiments with nitrocellulose membranes having lipid spots. 
RESULTS: GST-PSP-V5 was expressed in bacteria and purified with glutathione beads. rPSP-V5 bound to PtdIns( 3,4$) \mathrm{P}_{2}$ with a 10 -fold higher affinity than to $\operatorname{PtdIns}(3,5) \mathrm{P}_{2}$ or PtdIns(4,5) $\mathrm{P}_{2}$ and showed minimal binding to PtdIns $(3,4,5) \mathrm{P}_{3}$. No binding of rPSP-V5 was observed with PtdIns or PtdIns(3)P. The other proteins known to bind specifically to PtdIns $(3,4) \mathrm{P}_{2}$ are TAPP1 and $\mathrm{p} 47_{\text {phox }}$. Protein-lipid overlay assays found stronger binding of bacterially expressed rPSP than $\mathrm{p} 47_{\text {phox }}$ to $\operatorname{PtdIns}(3,4) \mathrm{P}_{2}$.rPSP-V5 bound PtdIñs $(3,4) \mathrm{P}_{2}$ with an affinity of $\mathrm{Kd}=30 \mathrm{pM}$. Bacterially expressed human PSP (Splunc 2) also bound to PtdInsPs with a lipid specificity similar to the rat PSP.

CONCLUSION: Binding of bacterially expressed affinity purified rat PSP to PtdIns $(3,4) \mathrm{P}_{2}$ indicates that PSP binds directly to PtdInsPs. The $\mathrm{K}_{\mathrm{d}}$ value shows that $\mathrm{rPSP}$ has a high binding affinity for PtdIns(3,4) $\mathrm{P}_{2}$. These results suggest that the observed binding of rat PSP to granule membranes may be by a direct interaction with PtdInsPs. We demonstrate for the first time that human PSP binds to the headgroup of $\operatorname{PtdIns}(3,4) \mathrm{P}_{2}$ 


\section{TABLE OF CONTENTS}

ACKNOWLEDGEMENTS ................................................................................. iii

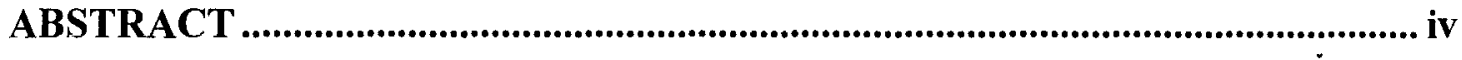

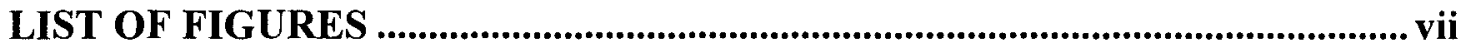

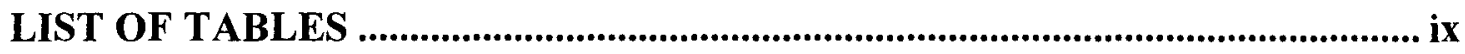

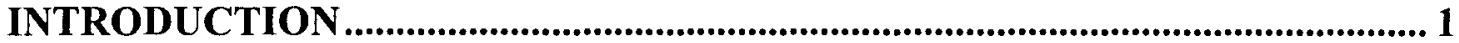

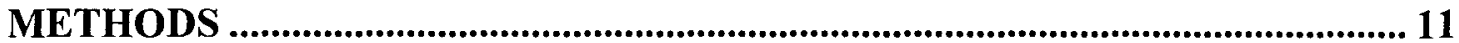

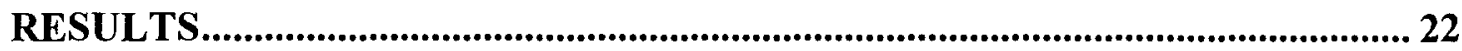

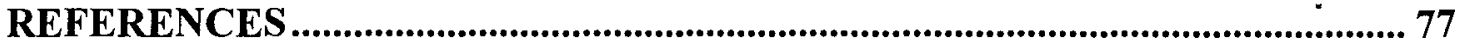

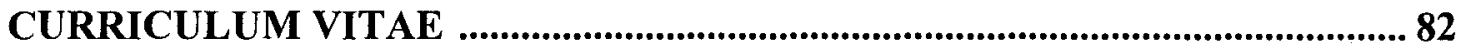




\section{LIST OF FIGURES}

Figure 1: Structure of Phosphoinositides. ............................................................ 8

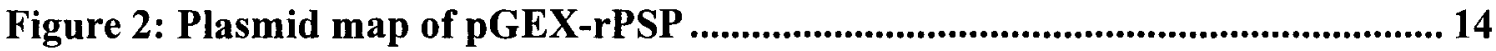

Figure 3: Restriction Cleavage sites present in the pGEX expression vector. .......... 19

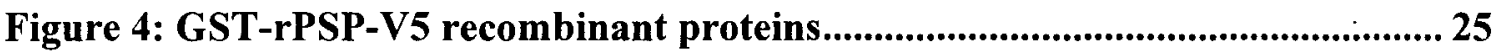

Figure 5: IPTG induction of GST fusion protein.............................................. 26

Figure 6: Expression of GST-rPSP-V5 fusion protein. ..................................... 28

Figure 7: Time course of protein expression after induction.................................. 30

Figure 8: Solubilization of GST fusion protein. ......................................................... 32

Figure 9: Effect of sarkosyl on solubilizing protein from inclusion bodies. .............. 33

Figure 10: Binding of GST-fusion protein with glutathione Sepharose 4B............. 35

Figure 11: Effect of Triton on binding.................................................................. 38

Figure 12: Effect of Triton and temperature on binding ...................................... 39

Figure 13: Elution of GST fused rPSP bound to glutathione beads. ......................... 42

Figure 14: Protease cleavage of GST-rPSP-V5................................................. 43

Figure 15: Induction of GST-2-rPSP-V5 and GST-2-V5................................. 46

.Figure 16: Characterization of expressed GST-2-rPSP-V5...................................... 47

Figure 17: Effect of ATP on protein purification .....................................................50

Figure 18: Changing the IPTG induction temperature.........................................52

Figure 19: PreScission protease cleavage of GST-2-rPSP-V5 .................................54

Figure 20: Phosphoinositide binding properties of rPSP-V5................................... 56 
Figure 21: Relative Binding of rPSP-V5 to different Phosphoinositides.................. 61 Figure 22: Protein-lipid overlay assay: Different concentrations of PtdIns(3,4)P $\mathrm{P}_{2}$.. 64 Figure 23: Protein-lipid overlay assay: Different concentrations of rPSP-V5 .......... 65

Figure 24: Binding Curve for PtdIns(3,4)P $\mathrm{P}_{2}$ binding to rPSP-V5 .......................... 66

Figure 25: Purification and Binding of GST-p47phox ......................................69

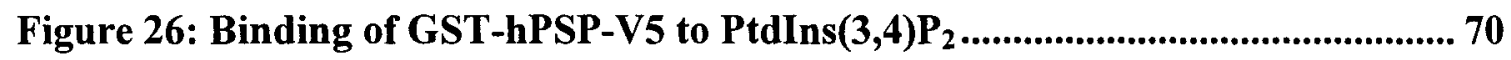

Figure 27: Amino acid sequence comparison of rPSP and hPSP .......................... 77 


\section{LIST OF TABLES}

Table 1: List of the clones for studying the expression and binding of Parotid

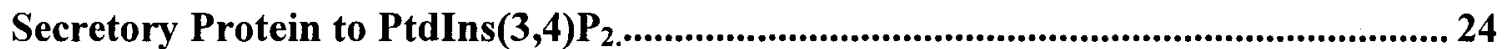

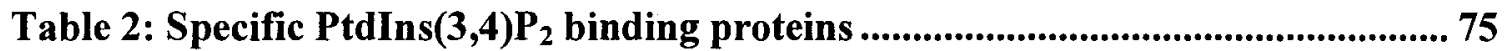

Table 3: Reported $K_{d}$ values of lipid binding proteins ........................................... 75

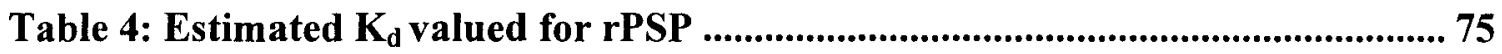




\section{INTRODUCTION}

\section{PAROTID GLAND}

The Parotid gland is one of the major salivary glands. It secretes salivary proteins including amylase, Parotid Secretory Protein (PSP), a family of Proline-Rich Proteins (PRPs) and less abundant proteins such as histatin and statherin [1]. Salivary proteins play an important role in host defense. They have antibacterial properties and have digestive functions like moistening food and helping in creating the food bolus. Peptides derived from PSP have been reported to have both antibacterial and anti-inflammatory properties making it an important salivary protein $[2,3]$. PSP also has been shown to have anticandidal properties [4]. The parotid gland is the largest salivary gland and the most frequent disorder associated with it is Sjogren's Syndrome, which affect $1-3 \%$ of the population, having a frequency of 1:5000 [5]. It leads to dry mouth and eyes as it is an inflammatory disease of exocrine glands. Xerostomia is the primary symptom of Sjogren's syndrome because of salivary gland hypofunction [6]. The salivary flow rate from the parotid gland in Sjogren's Syndrome falls to $0.291 \mathrm{~mL} / \mathrm{gland} / \mathrm{min}$ from a normal value of $0.672 \mathrm{~mL} /$ gland $/ \mathrm{min}$ [7], predisposing the patient to increased dental caries, and increasing the virulence of bacterial and fungal infections [8]. Many of these symptoms are due to the loss of salivary proteins, therefore it is important to understand the mechanism of protein sorting. 


\section{MECHANISMS OF PROTEIN SECRETION}

Regulated secretion of protein by salivary, pancreatic and endocrine glands requires the correct trafficking of soluble cargo proteins to the final destination. These cargo proteins are transported by vesicles termed 'secretory granules' which are formed at the trans-Golgi network (TGN) of the Golgi apparatus [9]. Secretory proteins are predominantly stored at high concentrations in the dense core secretory granules of both exocrine and endocrine glands [10].

Multiple potential post-Golgi pathways exist for intracellular trafficking of these secretory proteins. The major pathway in exocrine cells is the Regulated Secretory pathway wherein cargo proteins are stored in intracellular dense core granules until an extracellular stimulus is received to stimulate their release at the apical membrane of the cell [11]. It accounts for $80-90 \%$ of the salivary secretion from the parotid acinar cells [1]. Regulated secretion targets the cargo proteins to the apical surface and into the oral cavity. Alternatively, the constitutive pathway, which is common to all eukaryotic cells, secretes protein in the absence of any stimulation. The constitutive secretory pathways allow secretion from both the apical and basolateral (into the circulation) cell surfaces [1, 11-13]. The other secretory pathways are the minor regulated secretory pathway originating from maturing secretory granules, and the constitutive-like secretory pathway originating from secretory granules but not requiring any stimulation [1]. These latter two pathways are thought to be present based on kinetic arguments, and may contribute to salivation in the absence of neural stimulation. Given the presence of multiple pathways, the acinar cell must have a mechanism for sorting and trafficking (sorting) salivary proteins into the apical regulated pathway, and away from the basolateral 
constitutive pathways. Any cargo proteins (such as amylase) in the basolateral pathways are secreted eventually into the bloodstream, and are lost to the saliva.

\section{PROTEIN SORTING}

Delivery of the cargo proteins to specific post-Golgi vesicles involves processes collectively termed "Protein Sorting" [14-16]. It involves selective entry of the protein into the correct immature vesicle and retention of the protein as the vesicle matures [9, 17]. The vesicles containing the proteins from the trans-Golgi network (TGN) traffick them to their correct final destinations [18]. The TGN of all cells produce vesicles for multiple specific destinations, either to the cell surface or directed to intracellular compartments such as endosomes or lysosomes. Hence, correct protein sorting is a function that must be fulfilled by all cells from yeast to mammals. Cargo proteins destined for exocrine secretion into saliva must be sorted into the correct vesicles that will enter the Regulated Secretory pathway.

Two models have been suggested for protein being sorted into the vesicles from the trans-Golgi network. One is "sorting by entry", according to which protein gets sorted directly into the vesicle from TGN [17]. This could be derived from $\mathrm{pH} / \mathrm{Ca}^{++}$aggregation [19], or by association of protein with the lipid rafts present in the trans-Golgi network or the protein aggregate complex binding to the TGN membrane [20]. Thus for sorting into immature vesicles, aggregation is required [21]. The other model suggests "sorting by retention" for which all proteins enter the immature secretory granule unsorted, and the correct cargo proteins are retained in the vesicles as the vesicle matures and other proteins are removed during vesicle maturation [22]. Little has been done to distinguish 
between these models, but importantly both require sorting of the soluble cargo proteins at some point.

Sorting of specific cargo proteins has been suggested to require a membrane sorting receptor. Sorting receptors have been identified in pancreas and other tissues, but no sorting receptor is known in the parotid gland. There are a variety of receptors present on the vesicles which help in sorting of specific cargo proteins, for example, carboxypeptidase present on the vesicle membrane helps in sorting of ACTH in pituitary cells [9]. Secretogranin III has been shown to be a sorting receptor for chromogranin in pituitary and pancreatic $\beta$ cells [23]. However, no such sorting receptor has been reported for Parotid Secretory Protein (PSP), or for any other parotid protein. Also the $\mathrm{pH}$ and calcium induced protein aggregation leading to sorting of protein into secretory granules, as seen is endocrine cell lines [24] and exocrine pancreatic secretory granules [25], is not present in exocrine parotid gland protein sorting. It has been reported that the parotid secretory granule protein do not aggregate in vitro under high or low calcium conditions or at different $\mathrm{pH}$ conditions $[19,26]$.

Therefore, the mechanism of sorting of salivary proteins in the parotid is unknown. The key issue is to understand the molecular interactions of the proteins destined for regulated secretion, which cause sorting to the correct immature granule as it forms, or which cause retention of the protein in the granule as it matures.

To investigate the mechanism of sorting of protein into parotid secretory granules, the interaction of salivary cargo proteins with rat parotid secretory granule membranes was studied. PSP was the only major cargo protein that bound to the secretory granule 
membrane. The other major salivary proteins, Proline-Rich Protein (PRP) and amylase,

did not bind to the membranes. Subsequent experiments in Dr. Darling's laboratory found that PSP in crude extracts of parotid granules is able to bind to a rare membrane lipid, phosphatidylinositol $(3,4)$ bis-phosphate $\left(\operatorname{PtdIns}(3,4) \mathrm{P}_{2}\right)$. This is consistent with the role of phosphatidylinositol phosphates in anchoring proteins to specific regions of membranes, leading to trafficking of the protein [27]. Phosphoinositide-binding domains play critical roles in the intracellular localization of a variety of cell signaling proteins. The binding of PSP to PtdIns $(3,4) \mathrm{P}_{2}$ may contribute to sorting in the parotid, however, PSP lacks a recognizable phosphoinositide-binding domain, and may interact with membrane lipid through another protein. Therefore, it is necessary to purify PSP to demonstrate direct high affinity binding to $\operatorname{PtdIns}(3,4) \mathrm{P}_{2}$.

\section{PHOSPHOINOSITOL PHOSPHOLIPIDS}

Phospholipids form the bilayer of the cell membrane. One of the key constituents of the cell membrane is phosphatidylinositol (PtdIns). Its phosphorylated derivates are called phosphoinositides (PtdInsPs). There are 7 different phosphorylated forms of PtdIns due to different combinations of phosphorylation of 3 sites on the inositol ring (Figure 1). Phosphatidylinositol is a rare lipid constituting $1 \%$ of the total lipids [28]. Phosphorylated phosphatidylinositols constitute only $0.1 \%$ of the total lipids present in the eukaryotic cell [28]. Of the phosphoinositides, PtdIns(4)P and PtdIns(4,5) $\mathrm{P}_{2}$ are the most abundant, however, they are present as only $0.05 \%$ of the lipid [28]. Alternatively, PtdIns $(3,4) \mathrm{P}_{2}$ is of very low abundance, comprising only $0.0001 \%$ of membrane lipids. 
The synthesis of specific phospholipids is geographically restricted to certain membranes. The metabolism of the lipid determines its composition in an organelle. $\operatorname{PtdIns}(4,5) \mathrm{P}_{2}$ is present mainly at the plasma membrane. It plays an important role in endocytosis, by recruiting selective proteins (two subunits of the AP2 complexes, AP180, CALM, epsin) to the plasma membrane [29]. Alternatively, $\operatorname{PtdIns(3)P~is~predominantly~}$ present on endosome membranes. Many endosomal proteins such as Hrs and SARA contain PtdIns(3)P-binding domains (such as the FVYE and PX domains) which are required for localization to the endosome [30]. Similarly, PtdIns(4)P is localized to TGN complex, and is responsible for localization of specific proteins. $\operatorname{PtdIns}(3,4) \mathrm{P}_{2}$ is found mainly in the early endocytic pathway and plasma membrane [31]. The lipid components of the parotid secretory vesicles have not been reported.

Phosphoinositides directly affect membrane trafficking in all cells, which was first studied in yeast [32]. PtdIns(3)P has been shown to play an important role in membrane trafficking from Golgi to endosomes. There are many phosphoinositide binding modules which have been identified in numerous proteins. These phosphatidylinositol (PtdIns) phospholipids act as major determinants in localizing protein to their site of function by binding of specific domains of protein. For example, the interaction of the PX domain of Vam 7 with PtdIns(3)P targets it from the TGN to the yeast vacuole [33]. PX domains (120 amino acids) have been identified in more than 100 proteins. In proteins like Vam 7 [33], p47 phox [34], and SNX3[35] the PX domain binds to PtdIns(3)P targeting the proteins to their final destination. The interaction of $\mathrm{PX}$ domain containing proteins with PtdInsPs is important in protein sorting, vesicular trafficking and phospholipid metabolism [36]. There are many other PtdInsP- binding 
motifs such as PH (Pleckstrin homology) [37], FYVE [38], and ENTH (Epsin $\mathrm{NH}_{2}$ terminal homology) [39]. The ENTH domain interacts specifically with PtdIns(4,5)P2 leading to clathrin mediated endocytosis. PtdIns $(3,4) \mathrm{P}_{2}$ is bound by the PX domain of p47 $7_{\text {phox }}[34,40]$ and PH domain of TAPP1 and TAPP2 [41-44]. It is the combination of the protein and lipid which ensures proper localization of the protein and therefore proper function of the protein.

There are a number of human diseases which are linked to defects in PtdInsP signaling, including cancer and immunodeficiency disorder (X-linked agammaglobulinemina). Mutations in $\mathrm{p} 47_{\mathrm{phox}}$, including its PX domain, cause granulomatous disease [45]. These mutations interrupt the interaction with $\operatorname{PtdIns}(3,4) \mathrm{P}_{2}$ leading to chronic granulomatous disease. Signaling defects in $\operatorname{PtdIns}(4,5) \mathrm{P}_{2}$ contributes to human pathologies like cardiac failure, bipolar disorder and the genetic disorder Lowe syndrome [46]. 


\section{Figure 1: Structure of Phosphoinositides.}

A

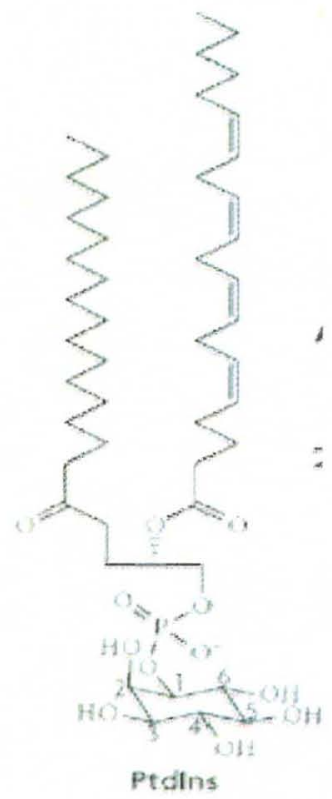

B
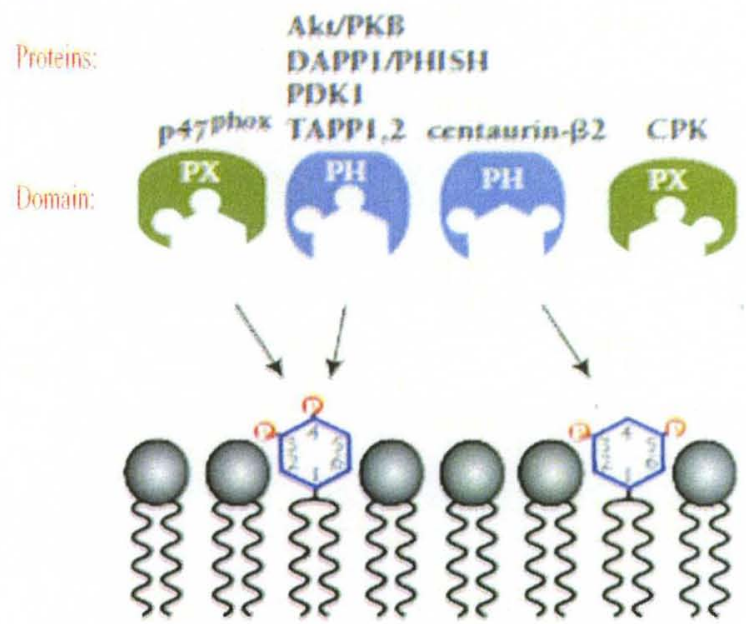

$\mathrm{PI}_{3}, 4 \mathrm{P}_{2}$

$\mathrm{P13}, 5 \mathrm{P}_{2}$

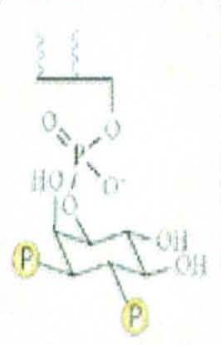

Ptdins $(3,4) \mathrm{P}_{\text {: }}$

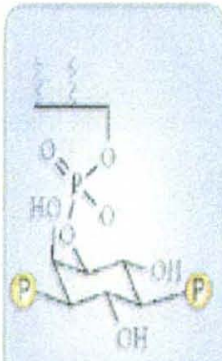

Ptdins $3,5,5$,

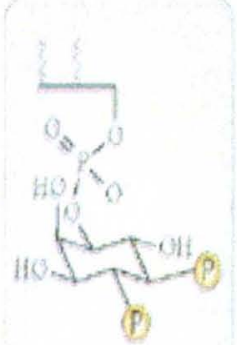

Ptdins $(4,5)$ P

$\mathrm{P}^{3} \cdot 4 \mathrm{P}_{2}$

Figure 1: A: The structure of the unphosphorylated and phosphorylated forms of PtdIns.

B: Lipid-binding domains such as $\mathrm{PH}$ or PX bind to specific PtdInsPs present in the membrane thus connecting the proteins to the phospholipids present on the membrane. PX domain of p47 phox and PH domain of TAPP1 specifically bind to $\operatorname{PtdIns}(3,4) \mathrm{P}_{2}$. Figure A is from [28], Figure B is from [47]. 


\section{IMPORTANCE OF PROTEIN SORTING}

It is important to understand protein sorting mechanisms. The parotid and submandibular glands have been suggested to be opportune sites for production of therapeutic transgenic peptides [48]. Also, since the regulated secretory pathway requires sorting signals, the peptide hormones for which no sorting signal have been devised, when transfected into the salivary gland takes a default pathway of constitutive secretion and gets secreted in blood stream. Considering this, a glucagon-like peptide was delivered systemically by gene transfer into salivary gland [49]. Salivary glands have also been used as the target sites for delivery of a therapeutic protein beneficial for oral cavity and upper GI tract. An Anti-candidal peptide c-DNA for histatin 3 was expressed in rat salivary gland and the transgenic gene produced was used against Candida albicans [50]. However, proteins that are normally secreted in an endocrine fashion, when placed into the salivary gland can enter the secretory pathway into the oral cavity, which is not therapeutically useful. Salivary glands are targets for gene transfer for protein deficiency syndromes such as involving growth hormone [51]. Failure to redirect the secretion of human growth hormone by the salivary gland from the regulated secretory pathway (into the saliva) to constitutive secretion (into the bloodstream) shows the inability to manipulate the regulated secretory pathway [52], as the mechanisms by which proteins are sorted to either secretory pathway are still not understood. Thus, increased understanding in secretory protein sorting will help in using salivary glands more efficiently as gene therapeutics.

The key issue is to understand the molecular interactions of proteins destined for regulated secretion, interactions which cause sorting to the correct immature granule as it 
forms, or which cause retention of the protein in the granule as it matures. PSP is one of the most abundant proteins in parotid saliva. Thus it is important to identify the mechanism of sorting of parotid secretory protein (PSP) in the parotid gland. My hypothesis is that In vitro purified Parotid Secretory Protein binds with a high affinity to PtdIns $(3,4) P_{2}$. To study this, rat PSP and human PSP were bacterially expressed and purified and binding studies were done using a protein-lipid overlay assay. 


\section{METHODS}

\section{CONSTRUCTION OF PLASMIDS EXPRESSING FUSION PROTEINS}

In order to study the in vitro protein purification of rat PSP (rPSP) and its binding affinity with the lipids, it was essential to express it as a fusion protein. Fusion vectors such as pGEX allow inducible and high level intracellular bacterial production of fusion proteins, and limit the formation of inclusion bodies. These vectors have been constructed to produce proteins of interest in E.coli as C-terminal fusions with the $26 \mathrm{kDa}$. glutathione-S-transferase (GST) protein [53]. A GST-rPSP fusion expression plasmid (Figure 2) was constructed by PCR. Since the mature PSP protein normally does not have the endoplasmic reticulum signal sequence, this 21 amino acid peptide was not included in the clones, which were termed deltaSS (dSS). A 14 amino acid V5 epitope was added to the $\mathrm{C}$ terminal end of rPSP to provide a tag for binding of the anti-V5 antibody, to identify and quantify the presence of the protein. The rPSP cDNA sequence was amplified by PCR using a cDNA clone of rat PSP as the template and primers which introduce unique flanking restriction enzyme sites. The two primers are: rPSP-EcoRev (5'- CAC CGA ATT CTC AGA GAG GGA CTG CTA GCT C-3') and BamPSPFor (5'CAC CGG ATC CCT TCT TGG TGA CGT TGC C-3') primers. Amplification was carried out for 30 cycles consisting of denaturation at $95^{\circ} \mathrm{C}$ for 10 minutes, annealing at $67^{\circ} \mathrm{C}$ for 45 seconds and extension at $72^{\circ} \mathrm{C}$ for 120 seconds. The PCR product was confirmed by agarose gel electrophoresis and purified from the gel by Qiagen QIAquick 
Gel Extraction Kit (as recommended by the manufacturer). The amplified fragment of rPSPdss and the pGEX expression vector were digested with BamH1 and EcoR1 enzyme and ligated. The mixture was then transformed into T10 competent cells and clone DNAs were extracted from bacterial colonies by miniprep. The plasmids were sequenced at the University of Louisville CGeMM Sequencing core, after which the correct clones were transformed into BL21 one shot star (DE3)pLysS competent bacteria. The pLysS plasmid carried by the BL21 (DE3)pLysS strain produces T7 lysozyme to reduce basal level expression of the gene of interest. The GST protein encoded in the pGEX vector (without rPSPdss) was also tagged with V5 antigen to be used as a control. Table 1 and Figure 4 shows the final clones fabricated and used for these experiments.

\section{VERIFYING BACTERIAL EXPRESSION OF PSP}

Individual colonies were inoculated in $10 \mathrm{~mL}$ of fresh $\mathrm{LB}$ medium along with ampicillin $(0.1 \mathrm{mg} / \mathrm{mL})$ and were incubated overnight at $37^{\circ} \mathrm{C}$ in a shaker (Environ Orbit shaker). An overnight culture $(1.5 \mathrm{~mL})$ was inoculated in fresh $5 \mathrm{~mL} \mathrm{LB}$ medium. The culture was incubated at $37^{\circ} \mathrm{C}$ until an optical density of 0.8 was reached. $20 \mu \mathrm{L}$ of sample was taken from the uninduced bacterial culture and centrifuged at 20,000 rpm for 5 minutes in a Beckman 22R centrifuge. The supernatant was discarded and the pellet was resuspended in SDS-PAGE sample buffer. Isopropyl $\beta$-d-thiogalactopyranoside(IPTG) of $0.1 \mathrm{mM}$ final concentration was added and incubated again at $37^{\circ} \mathrm{C}$ for additional 4 hours. IPTG specifically activates the expression of GST protein (or the GST-PSP protein) from the pGEX vector. To study the effect of IPTG at various time intervals, aliquots of induced bacterial culture were taken at different times over a period of 4 hours (15 mins, 30 mins, $45 \mathrm{mins}, 1 \mathrm{hr}, 2 \mathrm{hr}, 3 \mathrm{hr}$, and $4 \mathrm{hr}$ ). All the samples were 
centrifuged and the pellet was resuspended in the SDS-PAGE buffer. The samples were electrophoresed by SDS-PAGE and transferred onto a ployvinylidene fluoride (PVDF) membrane via western blotting. The membrane was probed with anti-V5 antibody to test for the expression of the protein.

\section{LARGE SCALE EXPRESSION}

To express large amounts of fusion protein, $50 \mathrm{~mL}$ of fresh $\mathrm{LB}$ medium was inoculated with the glycerol stock of the clone and incubated overnight at $37^{\circ} \mathrm{C}$ in Environ Orbit shaker. $2 \mathrm{~mL}$ of the overnight culture was added to a fresh $100 \mathrm{~mL}$ of LB medium and incubated at $37^{\circ} \mathrm{C}$ in a shaker till the optical density of 0.8 was reached. IPTG was added to the final concentration of $0.1 \mathrm{mM}$ and incubated further for 2 hours. The induced bacterial culture was centrifuged at $4000 \mathrm{rpm}$ at $4^{\circ} \mathrm{C}$ in $\mathrm{GH} 3.8$ rotor. The supernatant was discarded and the pellet was washed in $5 \mathrm{~mL}$ of ice cold phosphate buffered saline (PBS: $140 \mathrm{mM} \mathrm{NaCl}, 2.7 \mathrm{mM} \mathrm{KCl}, 10 \mathrm{mM} \mathrm{Na} 2 \mathrm{HPO} 4,1.8 \mathrm{mM} \mathrm{KH}_{2} \mathrm{P}_{4}$, $\mathrm{pH}$ 7.3) and $1 \mathrm{mM}$ phenylmethyl-sulfonyl fluoride (PMSF). The pellet was stored at $20^{\circ} \mathrm{C}$ for future use. 
Figure 2: Plasmid map of pGEX-rPSP

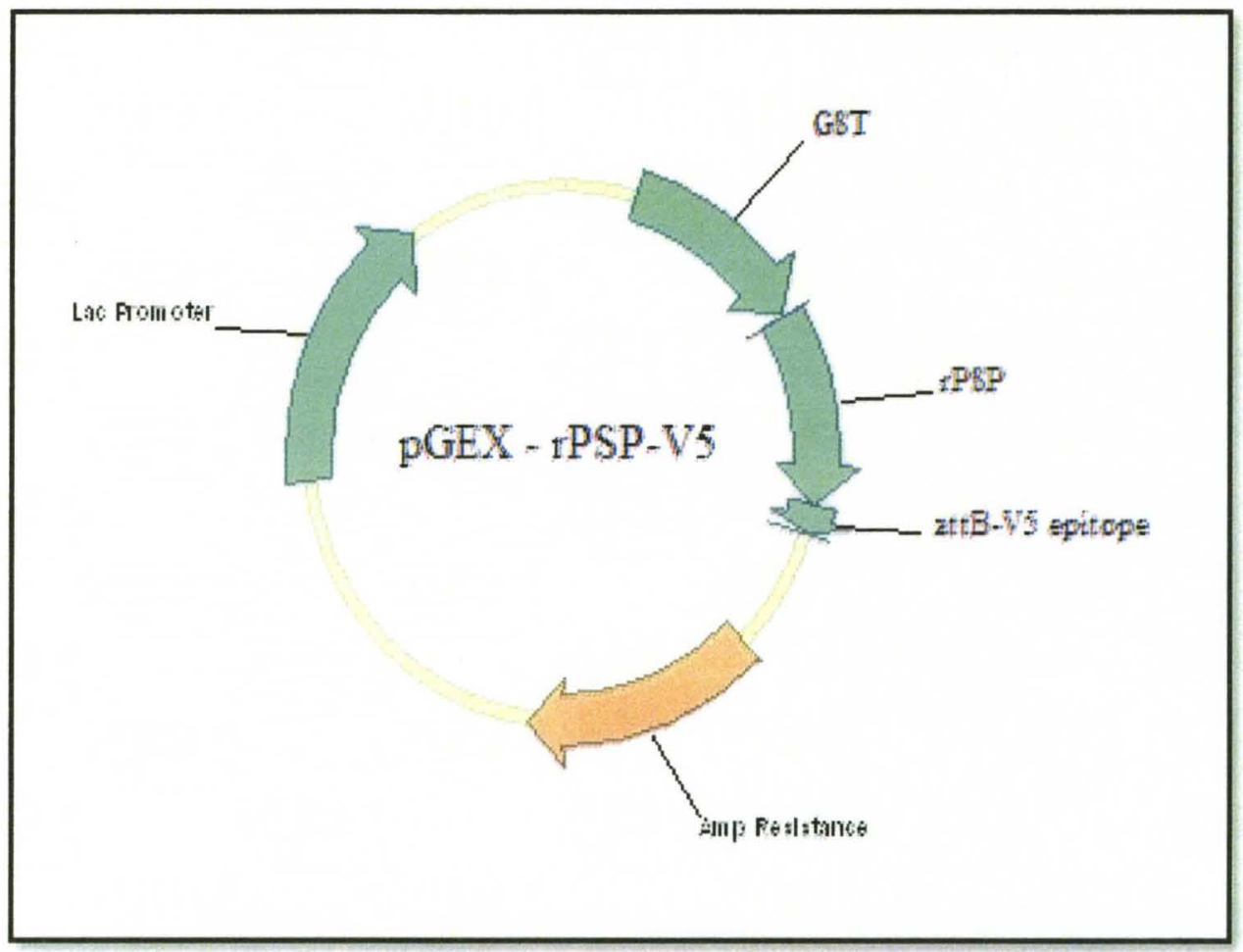

Figure 2: The rPSP cDNA was cloned into the pGEX expression vector. Expression vectors used were pGEX 4T-3 and the pGEX 6P-1. All the clones were tagged with a V5 antigen. 


\section{PURIFICATION OF THE BACTERIALLY EXPRESSED PROTEIN}

\section{A. SMALL SCALE}

The IPTG induced bacterial pellet (from $5 \mathrm{~mL}$ of bacterial culture; stored at $20^{\circ} \mathrm{C}$ ) was resuspended in $5 \mathrm{~mL}$ of ice cold PBS along with $1 \mathrm{mM}$ PMSF, 1 uM protease inhibitor cocktail (Protease inhibitor cocktail tablets- Roche Diagnostics), $5 \mathrm{mM}$ dithiotheritol (DTT) and $1 \mathrm{mM}$ ethylenediaminetetraacetic acid (EDTA). To the lysis buffer an ionic detergent, N-Laurylsarcosine (sarkosyl) (different concentrations, $0 \%$, $0.25 \%, 0.5 \%, 1.0 \%$ and $1.5 \%)$ were added to solubilize the protein as most of the protein was initially seen in the inclusion bodies. The lysed cells were sonicated for 4 cycles of 10 seconds each with duty cycle 2 and output 3 . Sonication was carried out on ice (Branson Sonicator). It was followed by centrifugation at $18,000 \mathrm{xg}$ for $20 \mathrm{~min}$ in a Beckman 22R centrifuge. The supernatant (bacterial lysate) was incubated with Glutathione Sepharose beads to allow affinity binding of the GST to the glutathione. Washed glutathione Sepharose 4B was made a 50\% (v/v) slurry in PBS. Aliquots (500 $\mu L)$ of the bacterial lysate were incubated with different volume of the glutathione Sepharose beads $(20 \mu \mathrm{L}, 60 \mu \mathrm{L}, 90 \mu \mathrm{L}, 150 \mu \mathrm{L}$ and $200 \mu \mathrm{L})$ at $4^{\circ} \mathrm{C}$ for an hour with constant end-to-end mixing. A separate set of aliquots were incubated at room temperature $\left(24^{\circ} \mathrm{C}\right)$ for an hour to test the temperature which gives maximum binding to the beads. Incubation was done with continuous agitation and later centrifuged at $1000 \mathrm{~g}$ for 1 minute. To increase the amount of protein binding to the beads, Triton X-100 ( $0 \%$ to $2 \%$ ) was added during the incubation of protein with beads. The protein bound to the beads was washed 5 times with 10 bed volumes of ice cold PBS along with $1 \mathrm{mM}$ PMSF. The beads were washed for 10 minutes with end to end mixing at $4^{\circ} \mathrm{C}$ followed by 
centrifuging at $1000 \mathrm{~g}$ for $1 \mathrm{~min}$. Elution buffer $(5 \mathrm{mM}, 15 \mathrm{mM}, 30 \mathrm{mM}$ or $50 \mathrm{mM}$ reduced glutathione) were added to the washed glutathione Sepharose beads in elution buffer (5 mM DTT, $1 \mathrm{mM}$ EDTA and $50 \mathrm{mM}$ Tris at $\mathrm{pH} 8$ ) to specifically elute the bound GST-fusion protein. After $1 \mathrm{hr}$ of incubation at room temperature with mild agitation the eluted protein was obtained by centrifuging the beads at $5000 \mathrm{x} g$ for 5 minutes. For storage, glycerol was added to the final concentration of $10 \%$ and the glutathione-eluted protein was placed at -80 degree $\mathrm{C}$.

\section{LARGE SCALE PURIFICATION}

The induced bacterial culture $(100 \mathrm{~mL})$ in pellet form which had been stored at $20^{\circ} \mathrm{C}$, was resuspended in $5 \mathrm{~mL}$ of the lysis buffer (1X PBS, $0.25 \%$ sarkosyl, $5 \mathrm{mM} \mathrm{DTT}$, $1 \mathrm{mM}$ EDTA, $1 \mathrm{mM}$ PMSF, $50 \mathrm{mM}$ Tris, $\mathrm{pH}$ 8) and sonicated 4 times for $10 \mathrm{sec}$ each while resting on ice. The sonicated bacterial culture was centrifuged at $18,000 \times \mathrm{g}$ for 30 min in a Beckman 22R centrifuge. The bacterial lysate supernatant $(1.5 \mathrm{~mL})$ was incubated with $200 \mu \mathrm{L}$ of glutathione Sepharose $4 \mathrm{~B}, 50 \%$ (v/v) for an hour at $4^{\circ} \mathrm{C}$ with continuous agitation. After centrifuging at $1000 \mathrm{xg}$ for 1 minute, the protein bound to the beads was washed with 10 bed volumes of washing buffer. The beads were washed 5 times to remove the non-specifically bound proteins. Each washing cycle lasted for 10 minutes at $4^{\circ} \mathrm{C}$ with continuous mixing followed by centrifugation at $1000 \mathrm{~g}$ for 1 minute.

The buffers used for each wash were as follows:

- $1^{\text {st }}$ and $5^{\text {th }}$ wash: $1 \mathrm{X}$ PBS $+1 \mathrm{mM} \mathrm{PMSF}+5 \mathrm{mM}$ EDTA

- $2^{\text {nd }}$ and $3^{\text {rd }}$ wash: $1 X$ PBS $+5 \mathrm{mM}$ EDTA $+5 \mathrm{mM}$ EDTA $+5 \mathrm{mM} \mathrm{ATP}+5 \mathrm{mM}$ $\mathrm{MgSO}_{4}+0.1 \mathrm{mg} / \mathrm{mL}$ denatured E.coli $+50 \mathrm{mM}$ Tris, $\mathrm{pH} 7.5$ 
- $4^{\text {th }}$ wash: $5 \mathrm{mM}$ ATP, $5 \mathrm{mM} \mathrm{MgSO}_{4}, 0.1 \mathrm{mg} / \mathrm{mL}$ Denatured E.coli, $50 \mathrm{mM}$ Tris, $\mathrm{pH} 7.5,350 \mathrm{mM} \mathrm{NaCl}$

Washing was followed by incubation with $200 \mu \mathrm{L}$ of the elution buffer $(15 \mathrm{mM}$ reduced glutathione, $1 \mathrm{mM}$ EDTA, $1 \mathrm{mM}$ DTT, $50 \mathrm{mM}$ Tris, $\mathrm{pH}$ 8). Elution was carried out for an hour at room temperature with mild agitation. Eluted protein (in the . supernatant) was obtained by centrifuging at $5000 \mathrm{xg}$ for $5 \mathrm{~min}$.

\section{CLEAVGE OF GST FUSION PROTEINS}

\section{THROMBIN CLEAVAGE}

rPSP was expressed in pGEX 4T-3 vector which contains a thrombin cleavage

site (Figure 3). Thrombin permitted cleavage of the rPSP protein from the GST tag. After washing the glutathione Sepharose beads, varying units of thrombin were added (ranging from $0 \mathrm{U}$ to $20 \mathrm{U}$ ) and incubation was carried out at $25^{\circ} \mathrm{C}$ for 4 hours to 16 hours. with mild end to end mixing. The cleaved protein was obtained by centrifuging the mixture at $3000 \mathrm{rpm}$ for 4 minutes.

\section{PRESCISSION PROTEASE CLEAVAGE}

The pGEX-6P expression vectors also permit convenient site-specific cleavage (Figure 3). Cleavage of rPSP from the GST portion of the fusion protein was carried out with PreScission Protease. $200 \mu \mathrm{L}$ of 50\% (v/v) glutathione Sepharose slurry was treated with 20 units $(10 \mu \mathrm{L})$ of PreScission protease enzyme in the cleavage buffer $(50 \mathrm{mM}$ Tris, $150 \mathrm{mM} \mathrm{NaCl}, 1 \mathrm{mM}$ EDTA, $1 \mathrm{mM} \mathrm{DTT}$, ph 7.0 ) for 4 hours at $4^{\circ} \mathrm{C}$ with end to 
end mixing. The cleaved protein was eluted by centrifuging at $500 \mathrm{xg}$ for $5 \mathrm{~min}$. Purified protein cleaved from the GST tag was stored at $-80^{\circ} \mathrm{C}$.

\section{GEL ELECTROPHORESIS AND WESTERN BLOTTING}

Protein samples were analyzed using 4-12\% acrylamide SDS-PAGE and imaged by silver staining, or staining with Coomassie Blue R250. Silver staining was done using the Thermo Scientific Pierce Silver Stain Kit. The image of the gel was captured on the Kodak imagestation.

Alternatively, proteins were detected by western blotting with specific antibodies. Protein in PAGE gels were transferred to PVDF membrane which was blocked with TTBS containing $2 \%$ Tween-20 for 20 min followed by overnight incubation with antiV5 antibody (Invitrogen R 960-25) (1:5000 dilution). The next day, the membrane was washed with TTBS for an hour, followed by incubation with a 1:5000 dilution of HRPconjugated anti-mouse IgG antibody. The signal was detected by Pierce chemiluminiscent mix on Kodak image station. The membrane was also probed with anti-PSP antibody. Relative optical instensities (ROIs) of the detected protein were recorded on the Kodak Imagestation. Analysis is performed using the pixel information on either the perimeter or on the interior contents of the band. 
Figure 3: Restriction Cleavage sites present in the pGEX expression vector.

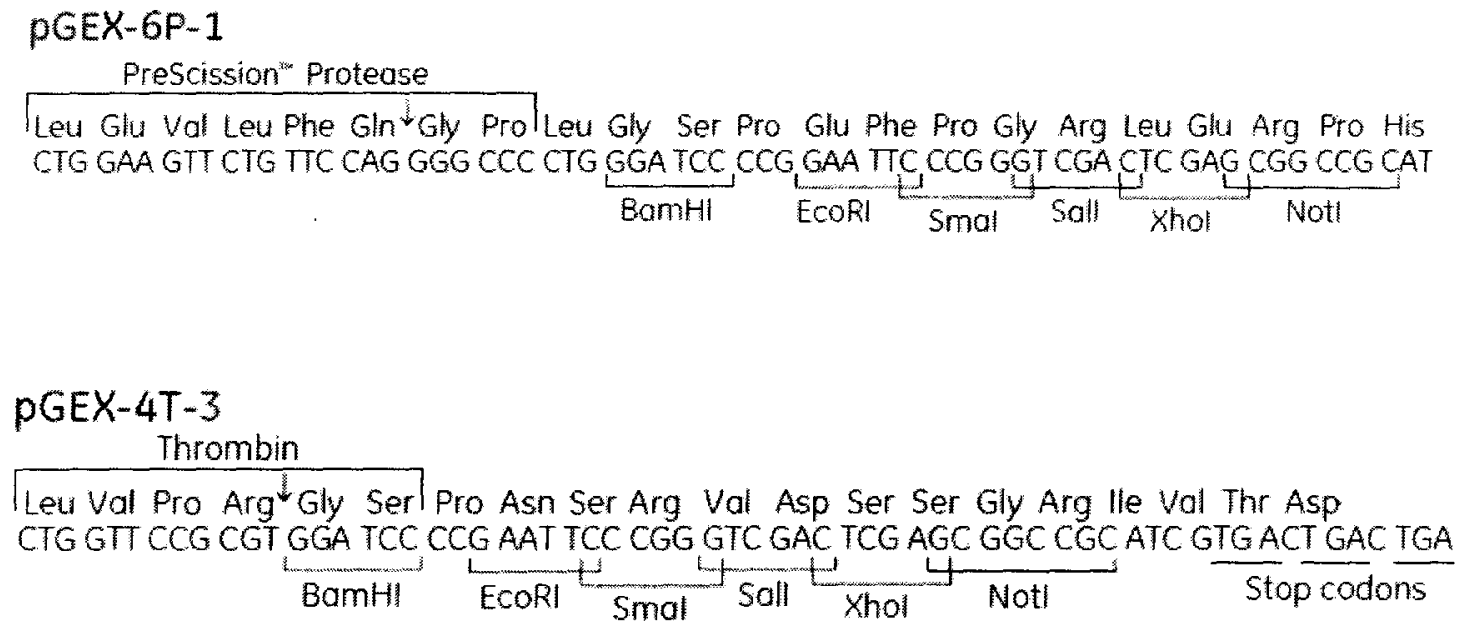

Figure 3: pGEX 6P-1 has the PreScission Protease cleavage site and the pGEX 4T-3

has the Thrombin cleavage site. The rPSP was inserted in between the BamH1 and EcoR1 restriction sites. 


\section{PROTEIN-LIPID OVERLAY ASSAY}

\section{DIFFERENT CONCENTRATIONS OF PHOSPHOINOSITIDES}

The ability of the PSP or GST-PSP fusion proteins to bind a variety of phosphoinositides was analyzed using a protein-lipid overlay assay. Lipid solution ( $1 \mu \mathrm{L})$ containing $6.25-200$ pmole of Phosphoinositides dissolved in chloroform/ methanol/water (1/2/0.8) was spotted on Hybond-C-extra nitrocellulose membranes and dried at $4^{\circ} \mathrm{C}$ for $1 \mathrm{~h}$. This created an array of spots with different concentrations of specific PtdInsPs. The membrane was blocked with $0.01 \%$ fat-free BSA in PBST (PBS, $0.1 \%$ Tween 20$) \mathrm{pH} 7.0$ at room temperature. The membrane was incubated with 1 $\mu \mathrm{g} / \mathrm{mL}$ of rPSP-V5 in the same buffer. Some experiments were blocked with PBST + $0.25 \%$ Tween (no BSA), and incubated with rPSP-V5 in PBST. After washing the membrane six times in PBST buffer, it was incubated with anti-V5-HRP antibody (Invitrogen) (1:5000 dilution) for $1 \mathrm{~h}$. The membrane was then washed six times with the PBST buffer and the signal was detected by Pierce chemiluminescent mix on the Kodak Imagestation. Relative Optical Intensity (ROI) was recorded for the protein bound to the phospholipids.

\section{DIFFERENT CONCENTRATIONS OF PROTEIN}

As an alternative experimental design, binding was quantified using a series of incubations with different concentrations of PSP-V5 protein. Nitrocellulose membrane was cut into $0.75 \times 0.75 \mathrm{~cm}$ squares. They were spotted in duplicate with lipid solution (1 $\mu \mathrm{L})$ containing 50 pmole of PtdIns or PtdIns $(3,4) \mathrm{P}_{2}$. After drying the membrane for $1 \mathrm{~h}$ at $4^{\circ} \mathrm{C}$, blocking was done with PBST containing $0.01 \%$ fat free BSA (Blocking buffer) 
for $1 \mathrm{~h}$. The membranes were incubated separately in the blocking buffer containing 0.1 to $3.5 \mu \mathrm{g} / \mathrm{mL}$ of $\mathrm{rPSP}-\mathrm{V} 5$ at room temperature. After $1 \mathrm{~h}$ incubation, the protein solution (free protein) was saved. All the membranes were washed with PBST six times and incubated with anti-V5 HRP antibody (1:5000) dilution for $1 \mathrm{~h}$ in PBST buffer. Membrane was washed for 1 hour and the signal was detected by Pierce chemiluminescent mix on Kodak Imagestation.

Since the goal of these experiments was to measure the binging of rPSP to lipids, it was important to quantify both the bound and free protein. To do this a standard curve was created by spotting known amounts of rPSP-V5 on to a nitrocellulose membrane. After protein incubation, free protein was spotted in duplicate on the nitrocelluloșe membrane. Both the membranes were air dried and blocking was done with PBST + $0.25 \%$ Tween for $1 \mathrm{~h}$. This was followed by one hour incubation with anti-V5 HRP antibody. The membranes were washed six times for $1 \mathrm{~h}$ with PBST. ROIs for the rPSPV5 were recorded on the Kodak Imagestation. The bound and the free protein concentrations were calculated using the standard curve. 


\section{RESULTS}

\section{CONSTRUCTION OF CLONES}

The clones created for this work are listed in Table 1 and Figure 4. Each pGEX clone was designed to express a GST fusion protein. Names of each fusion protein used in this study are listed in Table 1, column 5. All the clones showed the correct sequence and were successfully transformed into BL21 (DE3)pLysS competent cells. These clones were further confirmed by determining that the correct size GST fusion protein was expressed (Figure 5).

\section{INDUCTION OF pGEX 4T-3-rPSPdss-V5 by IPTG}

To test the expression of the GST-rPSP-V5 in E. coli BL-21 harboring pGEX 4T3-rPSPdss-V5, each of the clones were induced with IPTG (Isopropyl $\beta$-D-1thiogalactopyranoside). The bacterial cultures of pGEX 4T-3-rPSPdss-V5, pGEX 4T-3Human PSPdss-V5, pGEX 4T-3-Human PSPdss-V5 and pGEX 4T-3-V5 (see Table 1) were induced with IPTG. An overnight culture of bacteria was diluted 1:5 in fresh medium and incubated at $37^{\circ} \mathrm{C}$ until the bacterial culture reached log phase [53]. Before adding IPTG an aliquot of the bacterial culture was taken (uninduced sample). The uninduced sample acts as a negative control since without adding IPTG there should be no expression of protein. 
The remainder of the culture was induced with $0.1 \mathrm{mM}$ IPTG for 2 hours. Figure 5 shows a western blot probed with anti-V5 antibody. The samples were run on SDSPAGE. It can be seen that the uninduced lanes show no expression of protein as compared to the bands present in the induced lanes, which confirms the induction of GST-PSP-V5 fusion protein by IPTG. 
Table 1: List of the clones for studying the expression and binding of Parotid Secretory Protein to PtdIns $(3,4) \mathbf{P}_{2}$.

\begin{tabular}{|c|c|c|c|c|}
\hline $\begin{array}{c}\text { EXPRESSION } \\
\text { VECTOR }\end{array}$ & INSERT & TAG & FINAL CLONE & $\begin{array}{c}\text { PROTEIN } \\
\text { NAME }\end{array}$ \\
\hline pGEX 4T-3 & rPSPdss & attB V5 & $\begin{array}{c}\text { pGEX 4T-3- } \\
\text { ratPSPdss-V5 }\end{array}$ & $\begin{array}{c}\text { GST-rPSP-V5 } \\
-\end{array}$ \\
\hline pGEX 4T-3 & No insert & attB V5 & pGEX 4T-3-V5 & GST-V5 \\
\hline pGEX 6P-1 & rPSPdss & attB V5 & $\begin{array}{c}\text { pGEX 6P-1- } \\
\text { ratPSPdss-V5 }\end{array}$ & GST-2-rPSP-V5 \\
\hline pGEX 6P-1 & No insert & attB V5 & pGEX 6P-1-V5 & GST-2-V5 \\
\hline pGEX 4T-3 & $\begin{array}{c}\text { Human PSP } \\
\text { full length }\end{array}$ & attB V5 & $\begin{array}{c}\text { pGEX 4T-3-Human } \\
\text { PSP-V5 }\end{array}$ & $\begin{array}{c}\text { GST-hPSP(FL)- } \\
\text { V5 }\end{array}$ \\
\hline pGEX 4T-3 & $\begin{array}{c}\text { Human PSP- } \\
\text { dss }\end{array}$ & attB V5 & $\begin{array}{c}\text { pGEX 6P-1- } \\
\text { HumanPSPdss-V5 }\end{array}$ & GST-hPSP-V5 \\
\hline
\end{tabular}


Figure 4: GST-rPSP-V5 recombinant proteins

A

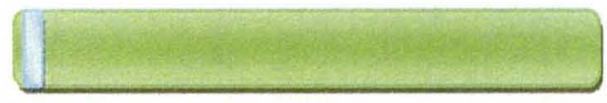

SS

PSP

B
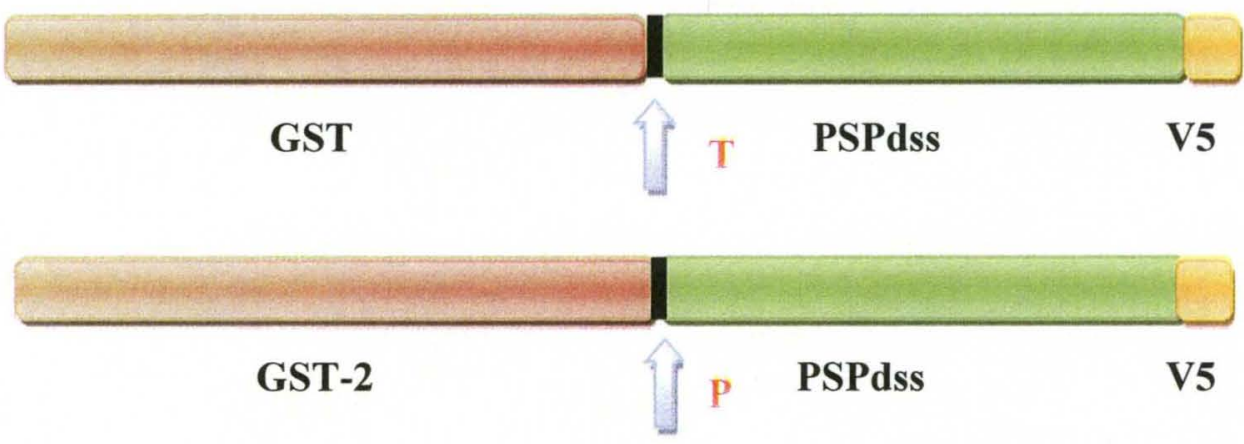

Figure 4: A: A cartoon of the original Parotid Secretory Protein (PSP) with the native signal sequence (ss) attached to it. B: The structure of GST-PSP-V5 fusion protein, with PSPdss fused to the GST protein along with a 14 amino acid V5 antigen tag. PSPdss has the $\mathrm{N}$ terminal sorting sequence deleted. The arrow indicates the location of the protease cleavage site present in the GST expression vectors. GST-PSP-V5 has the arrow indicating the Thrombin (T) cleavage site. In GST-2-PSP-V5 the arrow indicates the PreScission (P) Protease cleavage site. Clones expressing rat or human PSP were constructed with the pGEX expression vectors. 
Figure 5: IPTG induction of GST fusion protein.

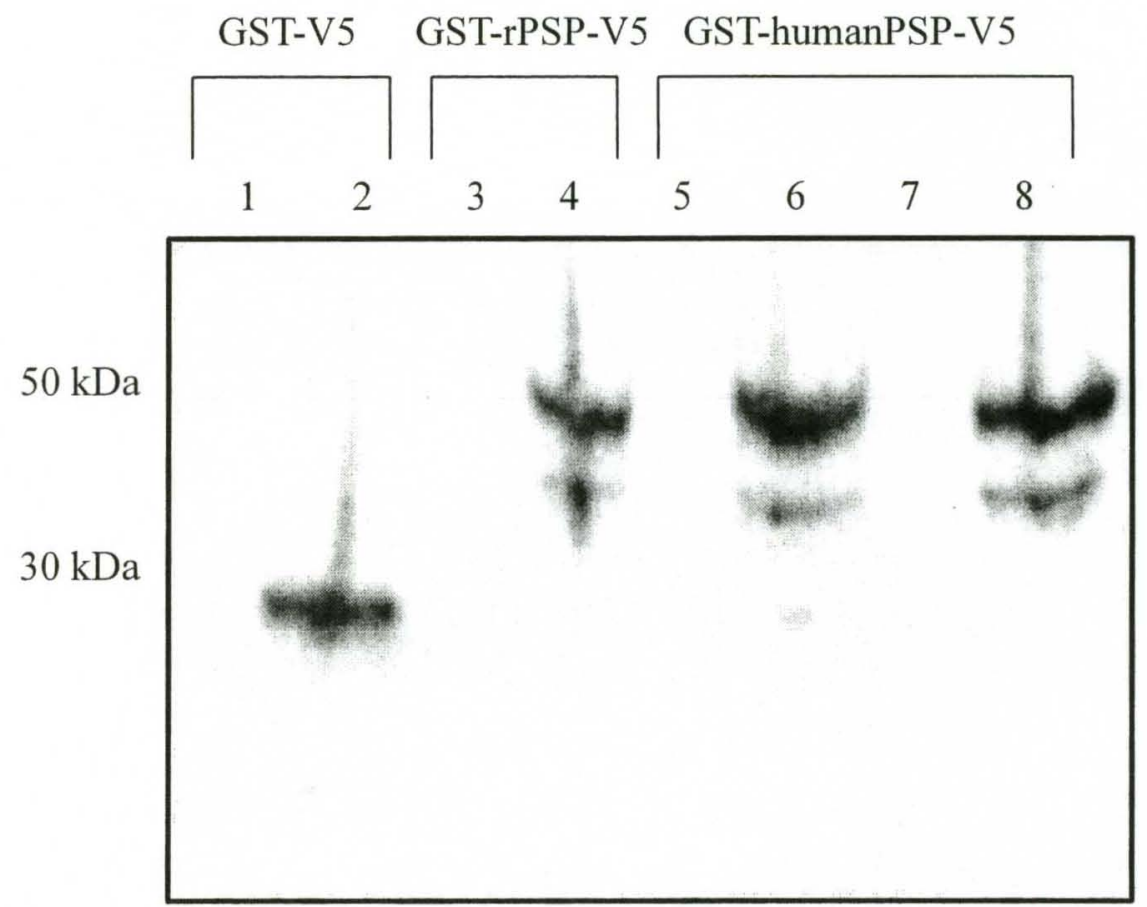

Figure 5: Aliquots $(40 \mu \mathrm{L})$ of the induced $(0.1 \mathrm{mM}$ IPTG) and uninduced bacterial cultures of GST-rPSP-V5, GST-hPSP-V5 and GST-V5 were taken and centrifuged. Samples were electrophoressed by SDS-PAGE followed by transfer to PVDF membrane. The membrane was probed with anti-V5 antibody. Lane 1, 3, 5, 7; Uninduced. Lane 2, 4, 6, 8; Induced. Lane 5 and 6 are the uninduced and induced for GST-hPSPdss-V5 (dssdeleted signal sequence). Lane 7 and 8 are uninduced and induced for GST-hPSP(FL)-V5 (FL- full lenght). 
The expected sizes of all the expressed proteins are seen. GST-V5 is $28 \mathrm{kDa}$, GSTrPSPdss-V5 is $54 \mathrm{kDa}$, GST-HumanPSPdss-V5 is $55 \mathrm{kDa}$ and GST-HumanPSP full length-V5 is $57 \mathrm{kDa}$.

In addition, the anti-V5 antibody detected a smaller protein apparently created by partial degredation of the expressed fusion protein. The presence of the C-terminal V5 tag, and the size of the protein indicates that it is produced by proteolytic cleavage within the GST portion of the fusion protein. Due to the presence of this protein additional experiments were done to optimize expression of the full length GST-PSP-V5 protein.

The goal of the next experiment was to define which concentration of IPTG would induce maximum expression of protein. To test this, bacterial cultures were induced with different concentrations of IPTG (0.1-1.0 mM). Before inducing with IPTG, an aliquot of the bacterial culture was saved as the uninduced sample (negative control). After IPTG induction for 2 hours, $40 \mathrm{ul}$ of sample was taken from each induced bacterial culture. All the samples were centrifuged, and the pellet obtained was resuspended in the SDS-PAGE buffer. The samples were electrophoresed on a 4-12\% acrylamide SDSPAGE. Figure 6 is a western blot probed with anti-V5 antibody. It can be seen that IPTG is necessary to induce expression, however, there is no significant difference in the expression of the protein between $0.1 \mathrm{mM}$ and $1.0 \mathrm{mM}$ IPTG induction. The expected size of the rPSPdss expressed as fusion protein with GST is $50 \mathrm{kDa}$. From this experiment onwards, I decided to induce the protein expression with a final concentration of $0.1 \mathrm{mM}$ IPTG [53]. 
Figure 6: Expression of GST-rPSP-V5 fusion protein.

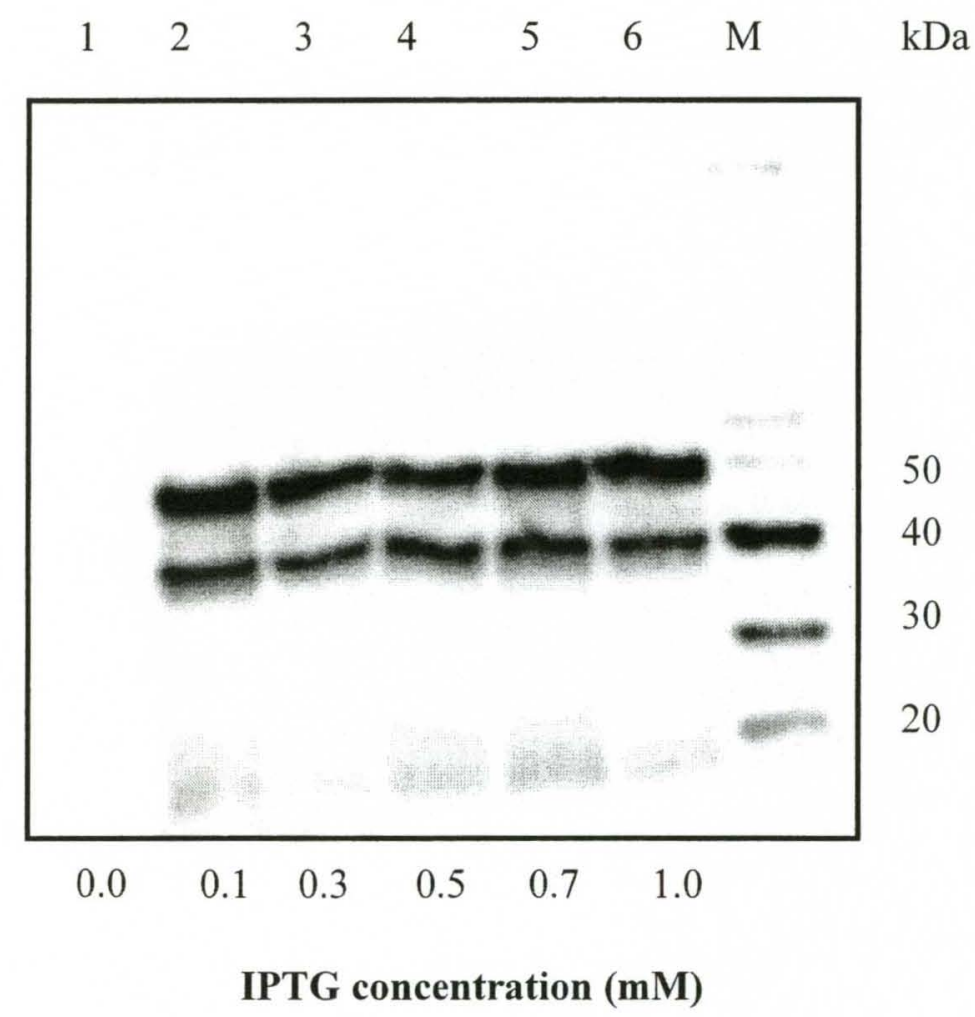

Figure 6: E.coli BL-21 containing the plasmid pGEX 4T-3-rPSPdss-attB V5 were grown at $37^{\circ} \mathrm{C}$, until the optical density reached 0.8 and then induced with $0.1 \mathrm{mM}$ to $1.0 \mathrm{mM}$ IPTG. Aliquots of the induced and uninduced bacterial culture were taken and centrifuged. Samples were analyzed by electrophoresis on SDS-PAGE. The gel was transferred to PVDF membrane for western blotting, followed by probing with anti-V5 antibody. Lane 1: uninduced (before adding IPTG). Lane 2-6: GST-rPSP-V5 induced with IPTG. M: Molecular size marker 
The optimal duration of IPTG induction varies with different proteins. Once the bacterial culture has grown to log phase, it is induced with IPTG to express the protein and incubation is done for different times depending on the clone. In all the experiments above, the IPTG induction time had been kept constant as 2 hours. However, it was necessary to determine the induction time which gives a maximum expression of GSTPSP protein. Therefore, an overnight culture was diluted with fresh LB medium and incubated till the optical density reached 0.8 , when it was induced with $0.1 \mathrm{mM}$ IPTG for different times and samples taken as described above.

The amount of protein expressed after induction increased with the increasing time. Figure 7 is a western blot of the SDS-PAGE probed with anti-V5 antibody. As seen from the figure, there is not a significant difference in the amount of protein expressed from 45 minutes and beyond. According to standard IPTG induction protocol, induction time should fall between 2 hours to 6 hours. Looking at the figure, I decided to keep the induction time at 2 hours. The above experiment was repeated three times to carefully define the optimum IPTG induction conditions.

My experiments demonstrated that GST fused rPSPdss was produced after IPTG induction in BL21 (DE3) bacteria. I found that induction with $0.1 \mathrm{mM} \mathrm{IPTG}$ for 2 hours gave the maximum yield of expressed fusion protein. 
Figure 7: Time course of protein expression after induction.

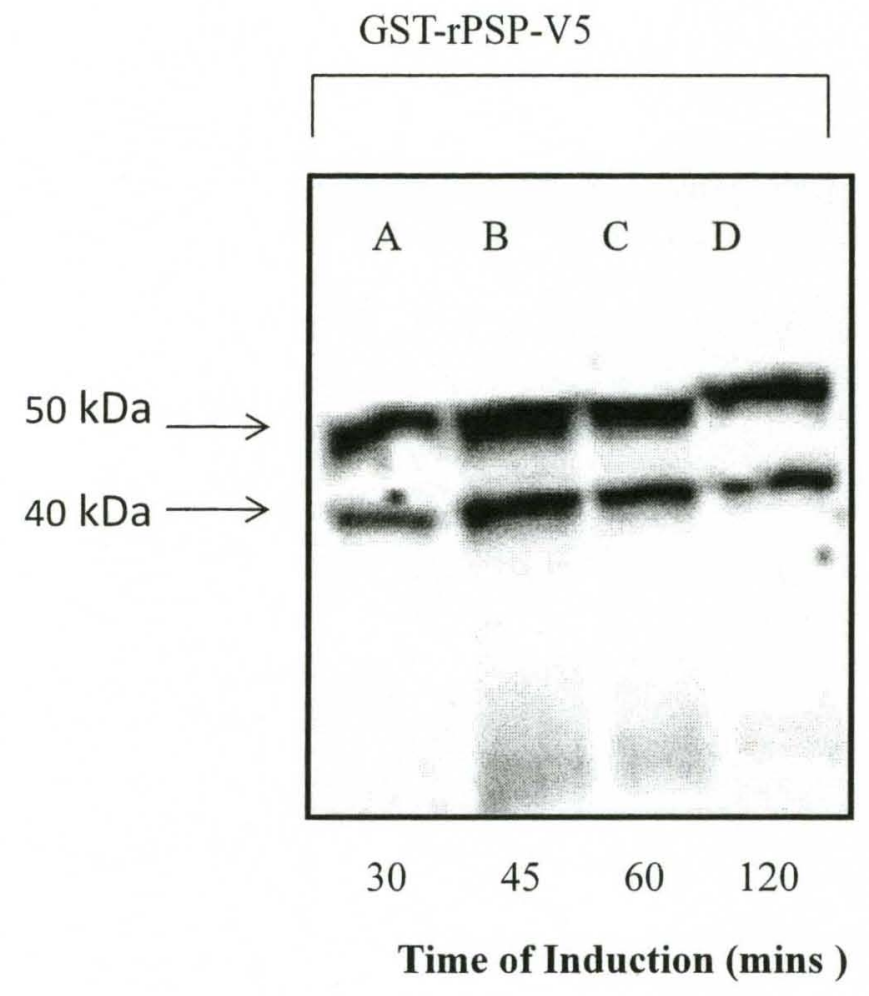

Figure 7: An overnight culture of cells transformed with pGEX 4T-3 was added to 10 $\mathrm{mL}$ of fresh medium, grown for $120 \mathrm{~min}$ and $0.1 \mathrm{mM}$ IPTG added. Samples $(20 \mu \mathrm{L})$ were taken at the times indicated and analyzed by SDS-PAGE, followed by western blot and probing with anti-V5 antibody. Lanes A to D: GST-rPSP-V5 induced for different times. 


\section{SOLUBILIZATION OF GST FUSION PROTEINS BY IONIC DETERGENTS}

Initial attempts to purify the protein were not successful as most of the GST fusion protein produced was partially or completely insoluble, likely due to formation of inclusion bodies. Therefore my next goal was to solubilize the protein into the supernatant. Addition of Sarkosyl to the lysis buffer has been effective in solubilizing protein from inclusion bodies at an early centrifugation step after cell lysis [54]. Therefore, five sets of induced bacterial pellets were resuspended separately in lysis buffer containing five different concentrations of sarkosyl $(0 \%, 0.25 \%, 0.5 \%, 1.0 \%$, and $1.5 \%)$. Following sonication and centrifugation, the pellet obtained was resuspended in SDS-PAGE buffer. The samples were analyzed by SDS-PAGE and western blotting probed with anti-V5 antibody (Figure 8). Comparison of lanes 1 and 2 shows that addition of sarkosyl largely solubilized the protein from the pellet. The sample with no sarkosyl had the maximum insoluble protein present. However, increasing the sarkosyl from $0.25 \%$ to $1.5 \%$ did not further decrease the amount of protein present in the inclusion bodies. As seen from the graph in Figure 9, there is a 6 fold decrease from $0 \%$ sarkosyl to $0.25 \%$ sarkosyl in the protein present in the inclusion bodies. Similar results were obtained with an additional experiment.

Therefore, adding $0.25 \%$ sarkosyl, an ionic detergent, helped in solubilizing most of the expressed GST-PSP-V5 fusion protein into the supernatant. 
Figure 8: Solubilization of GST fusion protein.

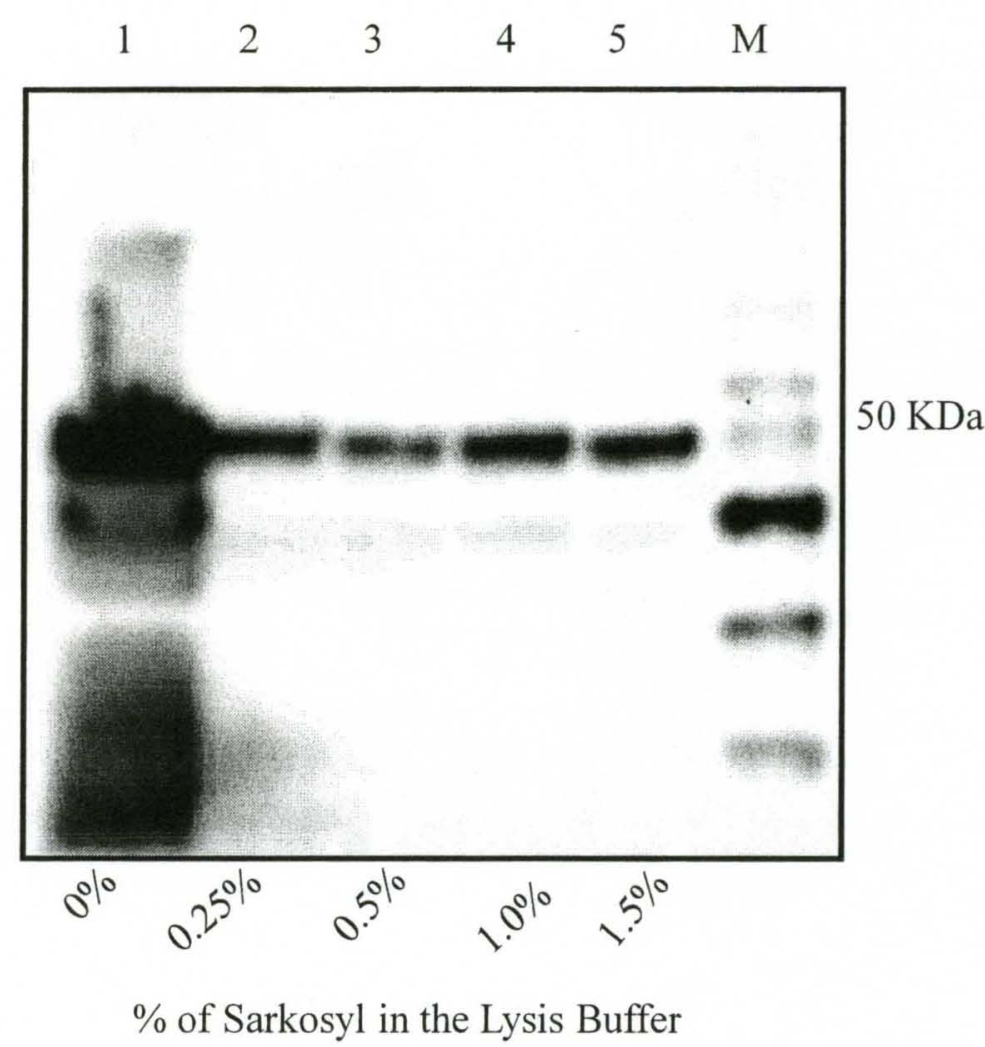

Figure 8: GST-rPSP-V5 bacterial lysates treated with sarkosyl (0-1.5\%) were centrifuged. 4X SDS-PAGE buffer was added to the pellet. Equal volumes of samples were electrophoresed on SDS-PAGE and later transferred to PVDF membrane for western blotting. The membrane was probed with anti-V5 antibody. Lanes 1 to 5: Band at $50 \mathrm{kDa}$ is GST-rPSP-V5. M: Molecular size marker. 
Figure 9: Effect of sarkosyl on solubilizing protein from inclusion bodies.

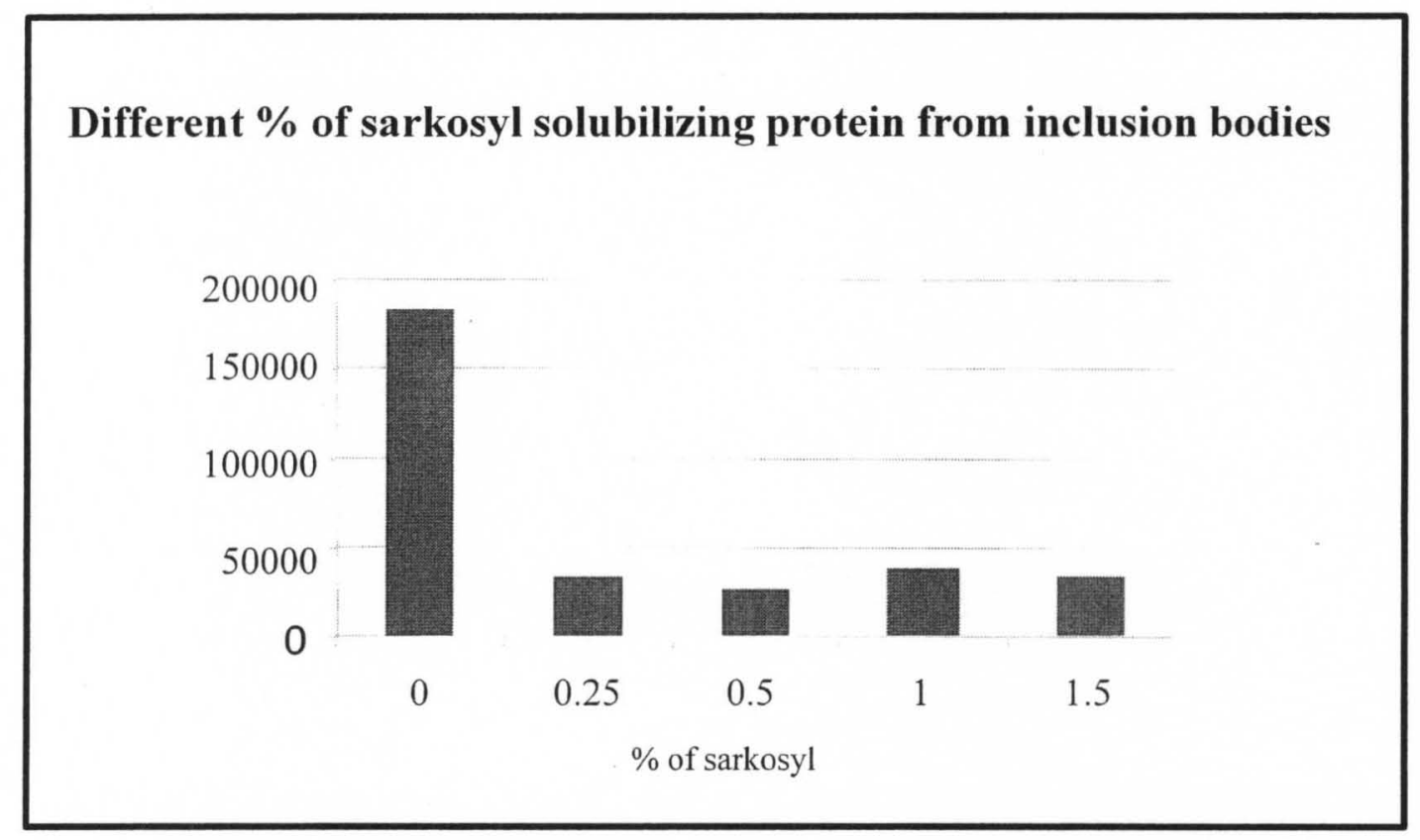

Figure 9: To study the effect of solubilization of protein with the effect of sarkosyl, ROIs of the band were recorded from the western blot (Figure 8) on the Kodak ImageStation and were plotted against the $\%$ of the sarkosyl added. There is a 6-fold decrease in the amount of protein present in inclusion bodies from $0 \%$ to $0.25 \%$ Sarkosyl. 


\section{BINDING OF GST-FUSION PROTEIN TO GLUTATHIONE SEPHAROSE 4B}

In order to partially purify the GST-PSP fusion proteins, glutathione Sepharose 4B affinity beads were utilized. The glutathione ligand on the glutathione Sepharose 4B is coupled via a 10-carbon linker to the Sepharose beads. The coupling is optimized to give a high binding capacity for GST-fusion proteins. GST fusion proteins can be purified directly from bacterial lysate using Glutathione Sepharose 4B by affinity purification. Binding of GST-PSP-V5 was tested by incubating a fraction of the lysate obtained by sonication of the bacterial culture, with $50 \%(\mathrm{v} / \mathrm{v})$ slurry of glutathione Sepharose 4B. To show a specific interaction, one of the tubes had no glutathione, only Sepharose 4B slurry. This was the negative control in the experiment as the GST tagged protein should bind only to the beads containing glutathione and not to the Sepharose. The mixture was centrifuged at $1000 \mathrm{xg}$ for $1 \mathrm{~min}$. The beads were washed several times with ice cold PBS and $1 \mathrm{mM}$ PMSF to remove nonspecifically bound protein. At the end of five washes, SDS-PAGE buffer was added to the pelleted beads. Samples were analyzed by a SDS-PAGE (Figure 10), and transferred to PVDF membrane followed by probing with anti-V5 antibody. The GST-fusion protein bound to the beads was easily identified as a major band that was absent in lane 1 , demonstrating an affinity forglutathione Sepharose and not for Sepharose alone. 
Figure 10: Binding of GST-fusion protein with glutathione Sepharose 4B.

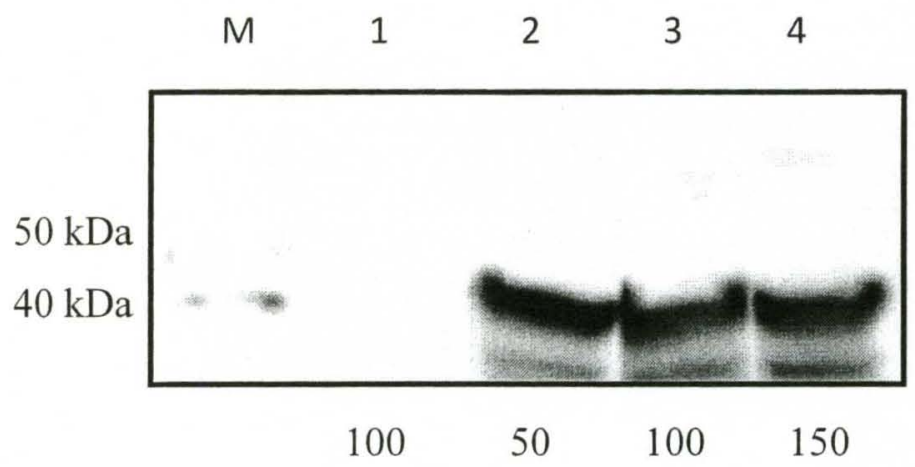

Sepharose 4B Glutathione Sepharose 4B

Figure 10: Glutathione Sepharose 4B and Sepharose 4B alone (control) beads with bound GST-rPSP-V5 protein were centrifuged and SDS-PAGE buffer was added to them Samples were electrophoresed on SDS-PAGE, followed by western blotting and probing with anti-V5 antibody. Lane 1: Sepharose 4B alone, Lanes 2-4: Glutathione Sepharose 4B. M: molecular size marker. 


\section{EFFECT OF TRITION ON BINDING OF GST TAGGED PROTEIN TO GLUTATHIONE SEPHAROSE 4B}

To get maximum binding to the beads, it was necessary to optimize the binding conditions. It has been reported that adding Triton X-100 was necessary for maximal binding of a particular fusion protein to the beads [55]. However, the effect of Triton varies with different proteins. Keeping this in mind, an experiment was performed with different amounts of Triton, ranging from $0-1 \%$, added to the binding reaction. Figure 11 displays a western blot probed with anti-V5 antibody. Bacterial lysate was aliquoted into small fractions, and different percentages of Triton were added. After incubating the lysate with the glutathione Sepharose $4 \mathrm{~B}$ slurry at $4^{\circ} \mathrm{C}$ and a quick spin, the protein bound to the beads was stripped off by SDS-PAGE buffer and analyzed by western blot. The amount of protein bound to the beads did not increase significantly on adding Triton. Therefore, Triton was not helpful for purifying GST-PSP-V5 and was not incorporated in the binding buffer.

\section{EFFECT OF TEMPERATURE ON BINDING}

Temperature has great effect on the binding of GST tagged fusion proteins to the beads. Both $4^{\circ} \mathrm{C}$ and $28^{\circ} \mathrm{C}$ have been proven to increase the binding efficiency [56], [53]. To optimize the binding temperature, GST-rPSP-V5 was incubated with glutathione Sepharose $4 \mathrm{~B}$ slurry at $4^{\circ} \mathrm{C}$ or at room temperature $\left(26^{\circ} \mathrm{C}\right)$. A fraction of the sonicated lysate was mixed with the beads and incubation was done with end to end mixing at 2

different temperatures. The mixture was centrifuged at $1000 \mathrm{xg}$ for a minute. Both bound and unbound fractions were analysed by SDS-PAGE. To the beads, 4 X SDS-PAGE 
buffer was added to elute the bound protein. Figure 12 is a western blot probed with antiV5 antibody. It can be seen from the figure that room temperature incubation did not have a significant effect on the amount of protein bound to the beads when compared to protein bound to beads at $4^{\circ} \mathrm{C}$ incubation.

These two sets of experiments were repeated three times, and it was concluded that adding Triton to the binding reaction, or incubating at room temperature did not significantly increased the amount of GST-PSP-V5 fusion protein bound to the beads. 
.Figure 11: Effect of Triton on binding

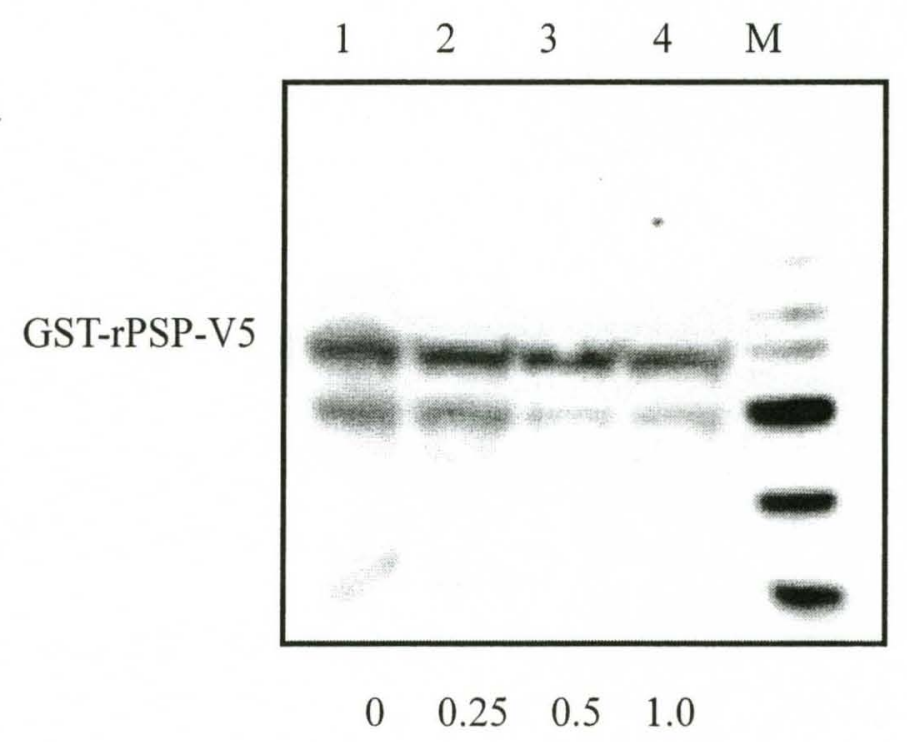

$\%$ of Triton X-100

Figure 11: Western blot of GST-rPSP-V5 bacterial lysate treated with different percentages of Triton during the affinity binding reaction, probed with anti-V5 antibody. The binding reaction was carried out at $4^{\circ} \mathrm{C}$. Addition of Triton does not increase the amount of protein isolated. Lane 1-4: different percentages of Triton. M: molecular size marker. 


\section{Figure 12: Effect of Triton and temperature on binding}

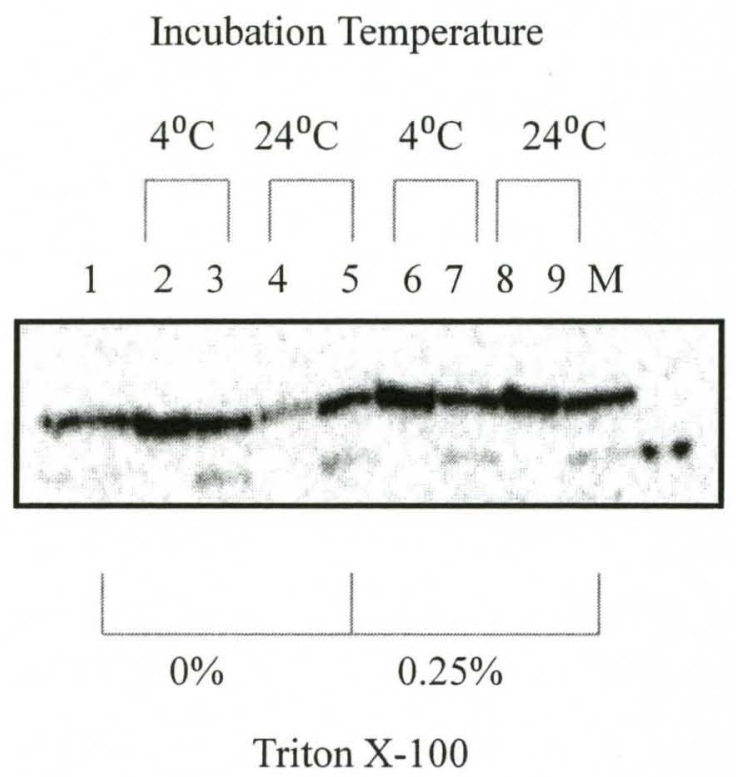

Figure 12: Western blot of Trition-treated GST-rPSP-V5 bacterial lysates bound to the beads at two different temperatures $\left(4^{\circ} \mathrm{C}\right.$ and room temperature). The blot was probed with anti-V5 antibody. Lane 2-5: 0\% Triton added to the binding reaction. Lane 6-9: $0.25 \%$ Triton added to the binding reaction. Lane $2,4,6,8$ : GST-PSP-V5 protein bound to the affinity beads. Lane 3, 4, 7, 9: Unbound protein. Lane 1: starting sample that went on to the beads. M: molecular size marker. 


\section{ELUTION OF THE GST FUSION PROTEIN}

The next goal was to optimize the conditions for elution of GST-PSP-V5 protein from the glutathione Sepharose beads using reduced glutathione. As per the standard elution protocol given by GE healthcare, the elution buffer consisted of $50 \mathrm{mM}$ Tris- $\mathrm{HCl}$,

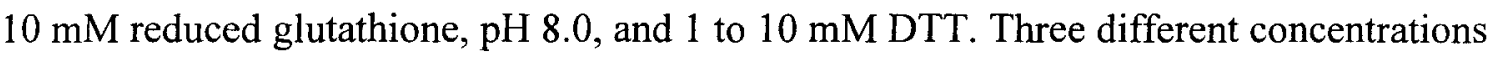
of reduced glutathione were tested $(5 \mathrm{mM}, 10 \mathrm{mM}$ and $15 \mathrm{mM})$. After 1 hour incubation at room temperature the beads were collected by centrifugation and the eluted protein was loaded on a SDS-PAGE. After electrophoresis the gel was transferred to PVDF

membrane and probed with anti-V5 antibody (Figure 13). The GST-rPSP-V5 protein was eluted with the correct band size of $50 \mathrm{kDa} .15 \mathrm{mM}$ reduced glutathione eluted a fairly good amount of protein.

\section{PROTEASE CLEAVAGE OF PURIFIED GST-rPSP}

The GST vector system is designed to allow cleavage of the fusion protein, releasing the protein of interest and leaving the GST protein bound to the glutathione Sepharose beads. After incubating the GST-rPSP-V5 with the beads, and washing the beads well with PBS and $1 \mathrm{mM}$ PMSF, the enzyme thrombin was added to the protein bound to the beads. For the enzyme reaction, $200 \mu \mathrm{L}$ of the affinity beads were used with $100 \mu \mathrm{L}$ of PBS buffer containing 20 units of thrombin (as per the manufacturer), and incubation was done at room temperature for 4 hours. Aliquots were taken after 2 hours and 4 hours of incubation. SDS-PAGE buffer was added to the beads left behind to strip off the uncleaved protein. Samples were analysed by SDS-PAGE and western blotting. In Figure 14, the majority of the GST-PSP-V5 protein is not successfully cleaved by thrombin, and remains bound to the glutathione Sepharose beads (lanes 2 and 4). A 
separate experiment was carried out in which the protein bound to the beads was incubated with thrombin for 16 hours. No significant increase in the amount of protein cleaved was observed in the 16 hour incubation. Even when glutathione was used to elute the GST-PSP-V5 fusion protein from the beads prior to treatment with thrombin, very little cleaved PSP was obtained (not shown). All these experiments lead to the conclusion that Thrombin is very ineffective in cleaving the GST-PSP-V5 protein. This may be due to folding of the protein in a way that conceals the cleavage site. 
Figure 13: Elution of GST fused rPSP bound to glutathione beads.

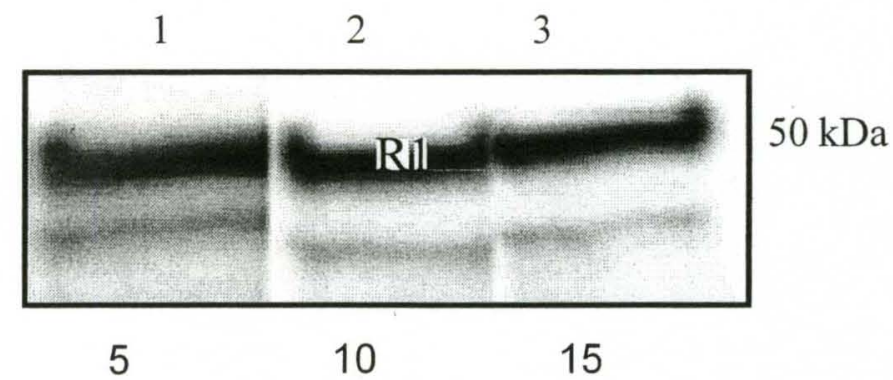

Reduced Glutathione (mM)

Figure 13: Western blot of the glutathione eluted GST-rPSP-V5 protein. Elution was tested with three different concentrations of reduced glutathione. Samples were analysed on SDS-PAGE followed by western blotting and were later probed with anti-V5 antibody. 
Figure 14: Protease cleavage of GST-rPSP-V5.

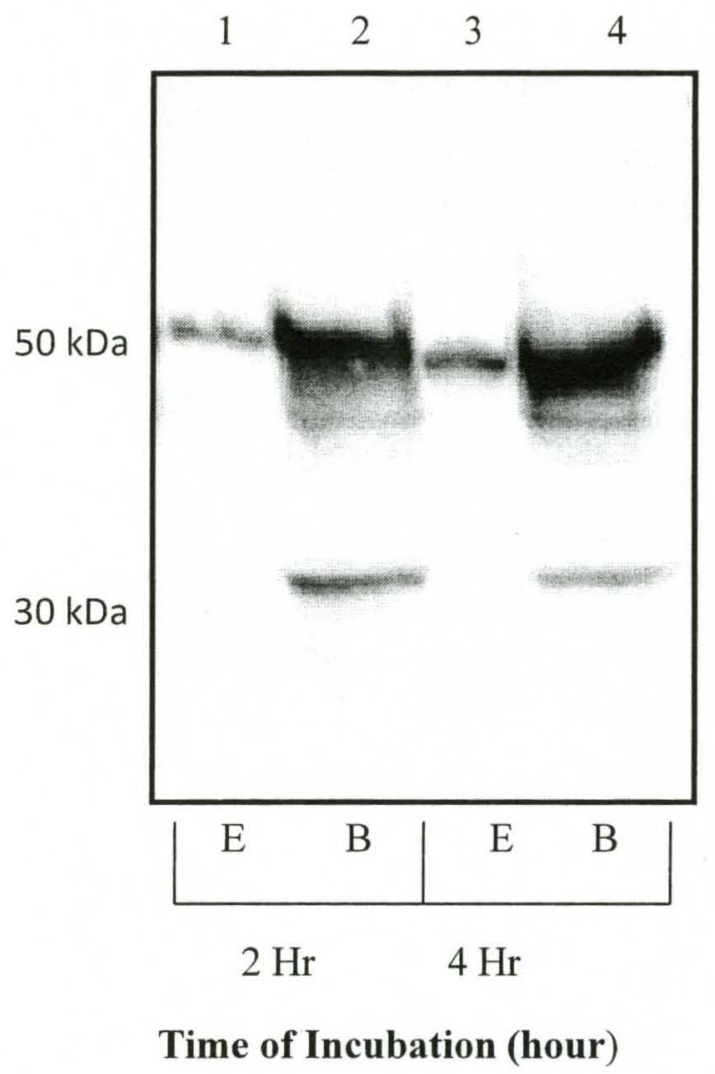

Figure 14: Thrombin treated GST-rPSP-V5 protein were electrophoressed on SDS-

PAGE followed by western blotting and probing with anti-V5 antibody. Lanes 1 and 3:

protein eluted (E) from the beads by Thrombin digestion after the cleavage. Lane 2 and 4 : remaining Bound (B) on the glutathione Sepharose beads. 


\section{INDUCTION AND PURIFICATION OF pGEX 6 P-1-rPSPdss attB V5}

Since the rPSP protein was not successfully purified using thrombin, the rPSP cDNA was cloned into a different GST vector containing the PreScission protease cleavage site. The pGEX-6P Expression Vectors permit site-specific cleavage and simultaneous purification on Glutathione Sepharose beads. PreScission Protease is a genetically engineered fusion protein consisting of human rhinovirus $3 \mathrm{C}$ protease fused to GST. This protease was specifically designed to facilitate removal of the protease by allowing simultaneous protease immobilization and cleavage of GST fusion proteins produced from the pGEX-6P vectors. Because PreScission Protease has been engineered with a GST tag, it binds to the glutathione beads and can also be removed from the cleavage mixture.

To test the expression of GST-2-rPSP-V5 and GST-2-V5, induction was done similarly as with pGEX 4T-3 expression vector. An overnight culture was diluted 1:5 in fresh medium, incubated until the optical density reached 0.8 , and was further induced with $0.1 \mathrm{mM}$ IPTG. As every expression vector acts in a different manner, the induction was carried for 4 hours and aliquots $(20 \mu \mathrm{L})$ of bacterial culture was taken after hour to check the amount of protein expressed. Before adding the IPTG, an aliquot was taken as the uninduced sample (negative control). All the samples were analysed by SDS-PAGE. Figure 15 is a western blot probed with anti-V5 antibody. As can be seen in lanes 1 and 5 , there is no expression of protein in the uninduced samples (before adding IPTG). Lanes 2, 3 and 4 show the expression of full length GST-2-rPSP-V5 protein $(50 \mathrm{kDa})$. Lanes 6, 7 and 8 show expression of GST-2-V5 protein (no insert; $26 \mathrm{kDa}$ ) [57]. Hence the constructs do express the correct size proteins. 


\begin{abstract}
Also, comparing the amount of protein expressed over a period of hours, no significant increase was observed when 2 hours was compared with 4 hours. Therefore, I decided to keep the induction time as 2 hours.
\end{abstract}

The expressed fusion proteins were characterized as described above. Figure 16 shows glutathione elution of GST-2-rPSP-V5 or the GST-2-V5. The samples were analyzed by western blotting. The membrane was probed with three different antibodies to characterize the expressed proteins (anti-V5 antibody, anti-PSP antibody, anti-GST antibody). It can be seen from the figure that the eluted GST-2-rPSP-V5 in lanes 1 and 3 show the correct size protein when probed with all three antibodies. The eluted GST-2V5 protein (lane 2) did not show any immunoreactivity when probed with anti-PSP (Figure 16 B), but bands were observed when probed with anti-V5 antibody and antiGST antibody (Fig. 14A\&C). Therefore, the expressed proteins were of the expected sizes and the expected immunoreactivities. 
Figure 15: Induction of GST-2-rPSP-V5 and GST-2-V5.

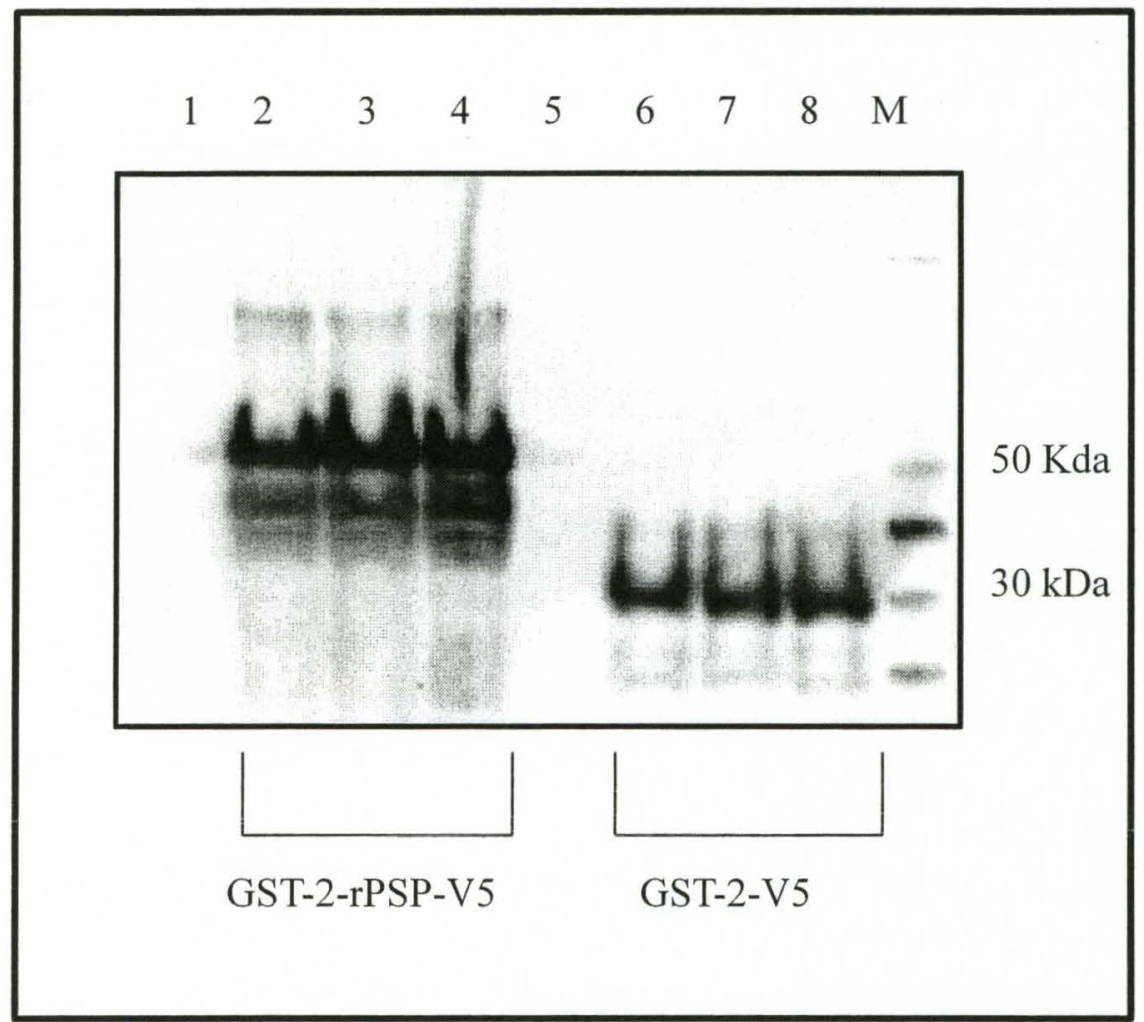

Figure 15: IPTG induced and uninduced bacterial samples were elelctrophoressed on a SDS-PAGE. It was then electro blotted and probed with anti-V5 antibody. Lane 1 and 5: uninduced sample; lane 2, 3 and 4: GST-2-rPSP-V5; lane 6,7and 8: GST-2-V5; M: Molecular size marker. 
.Figure 16: Characterization of expressed GST-2-rPSPdss-V5.

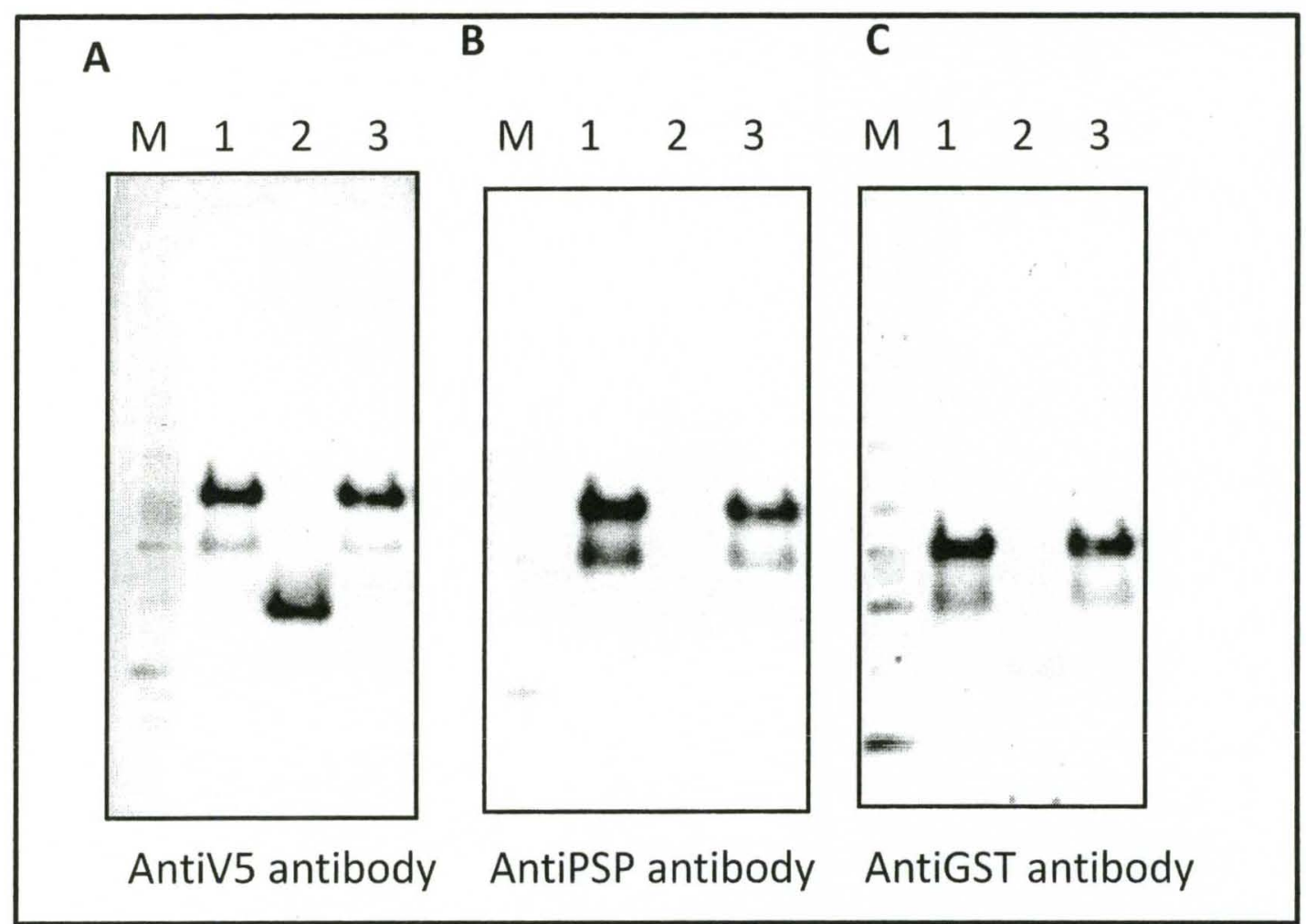

Figure 16: The glutathione eluted GST-2-rPSP-V5 samples were analysed on a SDSPAGE followed by western blotting. The membrane was probed with three different Antibodies. (A): anti-V5 antibody, (B): anti-PSP antibody, (C): anti-GST antibody. Lane 1, 3-glutathione eluted GST-2-rPSP-V5; lane 2: glutathione eluted GST-2-V5 (without the rPSP insert). M: Molecular size marker. 


\section{OPTIMIZING THE CONDITIONS FOR AFFINITY BEADS}

The next goal was to use silver-staining to help maximize the level of purity of the eluted protein. For this purpose aliquots were taken from each purification step, and proteins separated by SDS-PAGE. The gel was silver stained to detect all the major proteins present. In a silver stained gel multiple bands of protein were observed in the glutathione eluted protein (Figure 17). Therefore, additional steps for washing the affinity beads were investigated. It has been reported that the peptide region between GST and the fusion protein often binds E.coli DnaK, the bacterial Hsp70 (Heat shock protein 70) molecular chaperone homolog, resulting in an unwanted copurification of the chaperone with the fusion protein [58]. However, washing the fusion protein bound to the beads with $\mathrm{MgSO}_{4}, \mathrm{ATP}$, and denatured E.coli lysate before eluting the beads decreases copurification of the unwanted protein $[58,59]$.

Several different washing conditions were tried. The IPTG induced bacterial pellet of pGEX 6P-1-rPSPdss-V5 was sonicated and $1.5 \mathrm{~mL}$ of the bacterial lysate was bound to the glutathione Sepharose affinity beads (in each of 5 separate tubes), and incubated at $4^{\circ} \mathrm{C}$ for the binding reaction. The tubes were centrifuged and the bound protein and beads were washed with different buffers. The washed beads were incubated with the glutathione elution buffer for an hour at room temperature. The eluted proteins (1.5 ug) from each tube were analyzed by SDS-PAGE, and made visible by silver staining. In Figure 17, lanes 3-7 are the glutathione eluted proteins isolated after different washing conditions. Comparison of the starting lysate (lane 1) to the eluted samples (lanes 3-7) shows that affinity binding provides a dramatic purification of the GST-2-rPSP-V5 protein. The full-length GST-2-rPSP-V5 fusion protein is an abundant 
protein in the eluate (based on the apparent molecular size). Nonetheless, additional proteins are present. Washing the affinity beads with ATP, $\mathrm{MgSO}_{4}$ and denatured E.coli protein removed the approximately $80 \mathrm{kDa}$ proteins, consistent with the possibility that these are DnaK-related proteins. This improved the relative purification. An additional smaller protein of about $28 \mathrm{kDa}$ was present in the eluted fraction. This may be a Cterminal fragment of the GST-PSP-V5 fusion protein, and is discussed below.

Due to the improved purification, the washing conditions were modified for all subsequent experiments. They are as follows:

a. To keep the protein degradation minimal the entire purification experiment was performed at $4^{\circ} \mathrm{C}$ and protease inhibitors were added to the washing buffer.

b. The ionic strength was increased by adding $\mathrm{NaCl}$ to the washing buffer.

c. ATP, $\mathrm{MgSO}_{4}$ and denatured E.coli protein were added to one wash buffer to decrease the copurification of the putative DnaK protein.

d. The volume of the washing was increased to $1.5 \mathrm{~mL}$ for $200 \mu \mathrm{L}$ of the beads. Also the washing was done for 10 minutes with end to end mixing of the washing buffer and the beads. 
Figure 17: Effect of ATP on protein purification

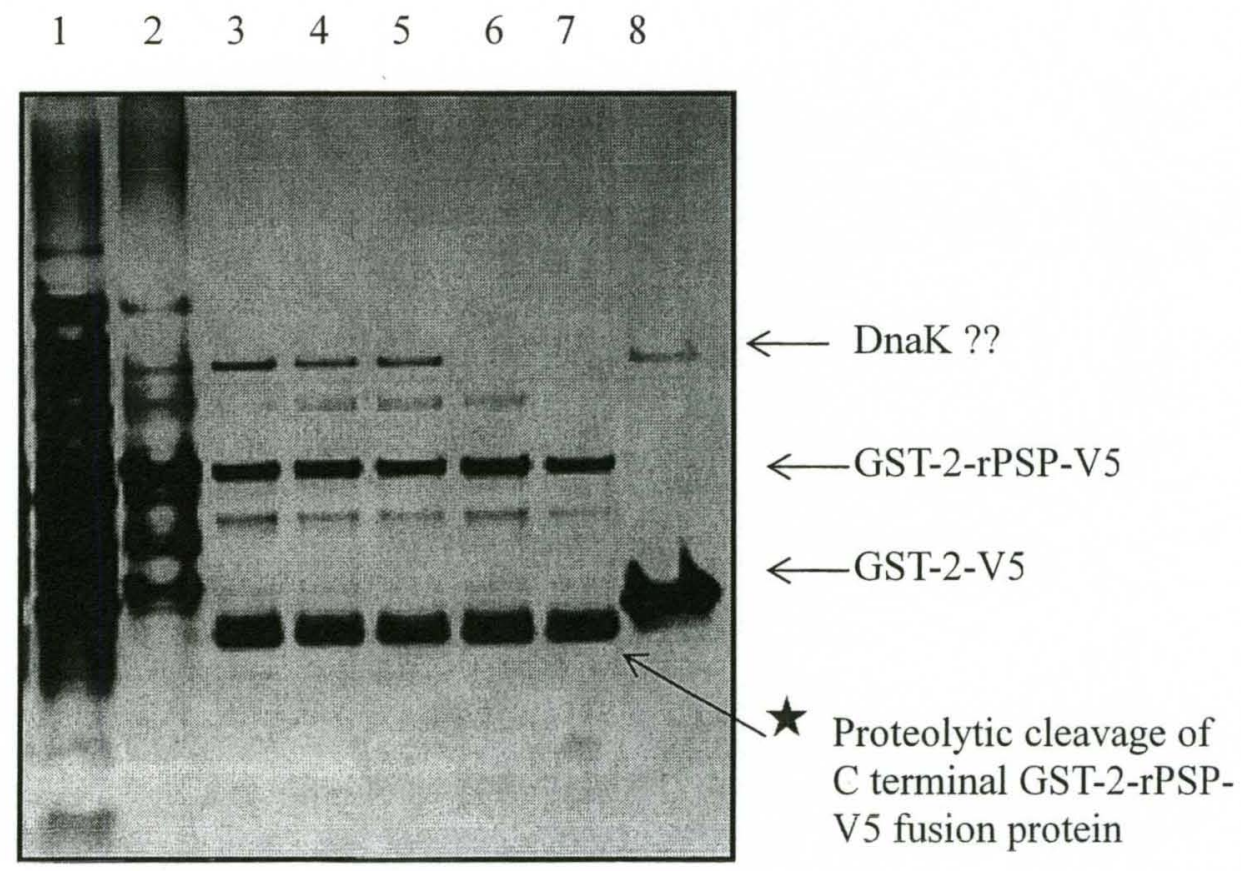

Figure 17: It is a silver stained gel. Aliquots from purification procedure were loaded on 4-12\% SDS-PAGE and were electrophoressed. After electrophoresis the gel was silver stained. Lane 1: bacterial lysate (starting sample) (13 ug); Lane 2: protein left on the beads after elution (3ug); Lane 4-7 GST-2-rPSP-V5 glutathione eluted protein; Lane 3: $150 \mathrm{mM} \mathrm{NaCl}$ in the washing buffer; Lane 4: $500 \mathrm{mM} \mathrm{NaCl}$ in the washing buffer; lane 5: $10 \%$ glycerol added to the washing buffer; Lane 6: ATP, $\mathrm{MgSO}_{4}$ and denatured E.coli protein added to the washing buffer; Lane 7: ATP, $\mathrm{MgSO}_{4}$ and denatured E.coli protein added to the bacterial lysate. Lane 8: GST-2-V5 eluted protein.

* The lower size band $(28 \mathrm{kDa})$ could be there due to proteolytic cleavage of $\mathrm{C}$ terminal of the fusion protein. 
With the additional washing steps, few contaminating proteins were present after affinity purification. However, smaller proteins which were immunoreactive with anti-V5 antibody were present, and were judged to be C-terminal fragments of the GST-2-rPSPV5 protein. The stability of fusion proteins can be increased by reducing the temperature of incubation during IPTG induction. Therefore, IPTG induction of GST-2-rPSP-V5 was tested at two temperatures and two IPTG concentrations. Figure 18 is a silver stained SDS-PAGE of affinity purified protein induced under different conditions. Improved expression of the full-length fusion protein was obtained at $26^{\circ} \mathrm{C}$ with $1 \mathrm{mM} \mathrm{IPTG}$. Thus lowering the induction temperature and increasing the IPTG concentration produced more active GST-2-rPSP-V5. 
Figure 18: Changing the IPTG induction temperature

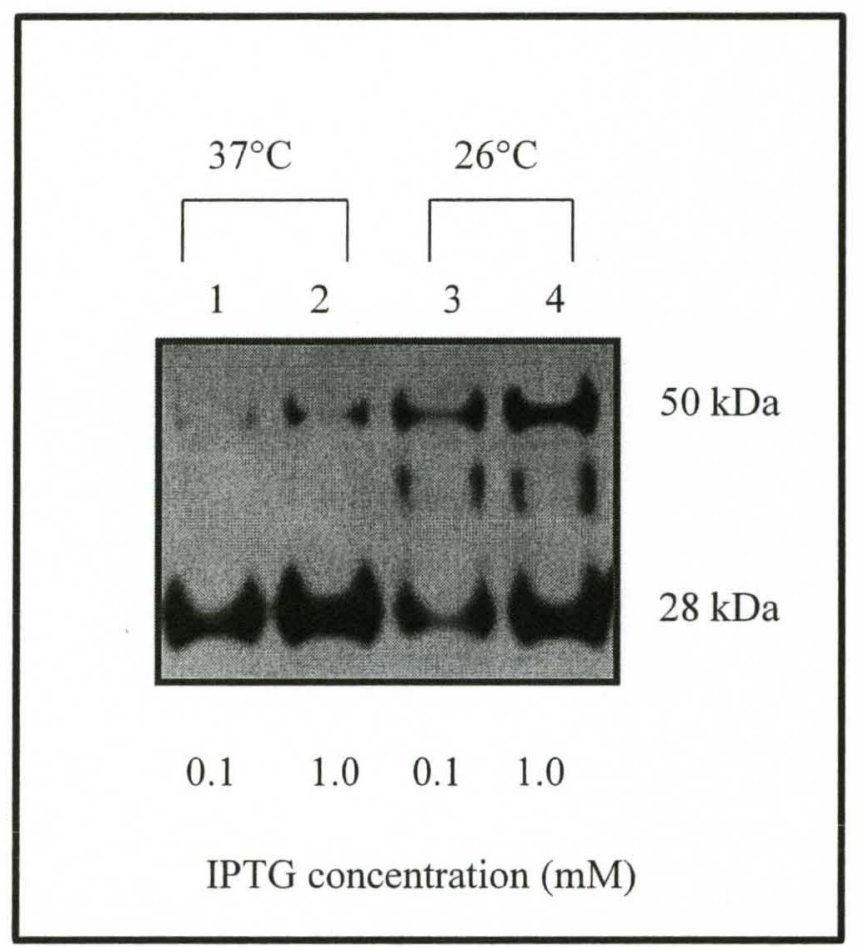

Figure 18: The glutathione eluted protein from all the induced pellets were loaded on 4$12 \%$ SDS-PAGE for electrophoresis followed by silver staining. Lane 1 and 2: Bacterial culture induced at $37^{\circ} \mathrm{C}$, Lane 3 and 4 : Bacterial culture induced at room temperature $\left(26^{\circ} \mathrm{C}\right)$ 


\section{PRESCISSION PROTEASE CLEAVAGE}

While the Thrombin cleavage did not produce useful rPSP protein (Figure 14), the newer clone in pGEX 6P is designed to cleave the rPSP from GST using PreScission Protease enzyme. An initial experiment tested the utility of PreScission protease. Three aliquots of $1.5 \mathrm{~mL}$ bacterial lysate were incubated with $200 \mu \mathrm{L}$ of glutathione Sepharose 4B beads for an hour. The protein bound to beads was washed as described above. Glutathione elution buffer $(200 \mu \mathrm{L})$ was added to one tube and was incubated for an hour at room temperature. The other two tubes were then equilibrated with the cleavage buffer (50 mM Tris pH 7.0, $150 \mathrm{mM} \mathrm{NaCl}, 1 \mathrm{mM}$ EDTA, and $1 \mathrm{mM}$ DTT). The protein bound to the beads was thoroughly washed for $10 \mathrm{~min}$ with end to end mixing at $4^{\circ} \mathrm{C}$ followed by a quick spin. Fusion protein bound to $200 \mu \mathrm{L}$ of affinity beads was incubated with 16 units $(8 \mu \mathrm{L})$ of enzyme resuspended in $192 \mu \mathrm{L}$ of the cleavage buffer. The optimum temperature for cleavage is $4^{\circ} \mathrm{C}$. Incubation time varies from protein to protein, and it ranges from 4 to 16 hours. The beads were incubated with the enzyme at $4^{\circ} \mathrm{C}$ with end to end mixing. After 4 hour incubation, one tube was centrifuged for $45 \mathrm{~min}$ at $500 \mathrm{xg}$. The other tube was centrifuged after 16 hour of incubation. The PreScission protease eluted protein from both the tubes and the glutathione eluted protein were analyzed by SDSPAGE and western blot. Figure 19 is a western blot probed with anti-V5 antibody. The glutathione-eluted control (lane 1), shows the expected size of the GST-2-rPSP-V5 fusion protein. PreScission protease-eluted protein (lanes 2 and 3) shows an additional prominent protein slightly smaller than $30 \mathrm{kDa}$, which is the expected size for rPSPdssV5. Incubation with the PreScission enzyme for 16 hours did not increase the amount of cleaved protein. 
Figure 19: PreScission protease cleavage of GST-2-rPSP-V5

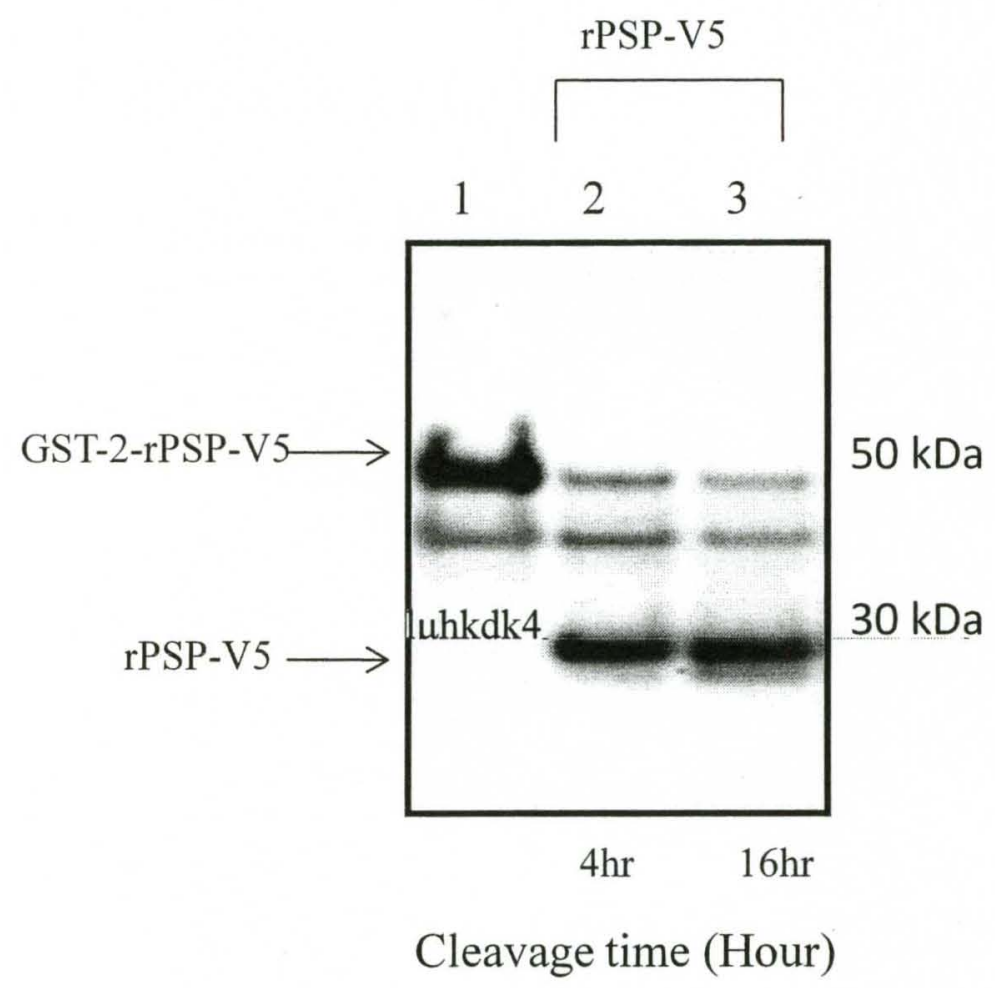

Figure 19: To one fraction of the glutathione beads bound with GST-2-rPSP-V5, glutathione elution buffer $(15 \mathrm{mM})$ was added and to another two fractions 16 units of PreScission protease enzyme was added and were incubated for 4 hours and 16 hours respectively. Lane 1 is the glutathione eluted protein, lanes 2 and 3: PreScission Protease eluted protein. 


\section{PROTEIN-LIPID OVERLAY ASSAY}

The above results demonstrate that this protocol produces a relatively purified preparation of rPSP-V5. To study the specific binding of rPSP-V5 to lipids, this bacterially expressed and purified protein was used. The binding studies were done using protein-lipid overlay assays [60]. The experimental designs are very similar to that used to study other PtdInsP-binding proteins $[34,37]$. The specificity of binding of rPSP-V5 to PtdIns $(3,4) \mathrm{P}_{2}$ is clearly demonstrated in Figure 20. Affinity purified, PreScission-eluted rPSP-V5 protein $(1 \mu \mathrm{g} / \mathrm{mL})$ was incubated for $1 \mathrm{~h}$ with a nitrocellulose membrane spotted with serial dilutions $(200,100,50,25,12.5,6.25 \mathrm{pmol})$ of each of the following lipids: PtdIns, PtdIns(3)P, PtdIns(3,4) $\mathrm{P}_{2}, \operatorname{PtdIns}(3,5) \mathrm{P}_{2}$, PtdIns(4,5) $\mathrm{P}_{2}$ and $\operatorname{PtdIns}(3,4,5) \mathrm{P}_{3}$. After washing, the binding was detected by probing the membrane with anti-V5 antibody. rPSP-V5 bound to as low as 6.25 pmol of PtdIns $(3,4) \mathrm{P}_{2}$, but did not bind with similar affinity to any other phosphoinositides. Thus rPSP-V5 has specific binding affinity for PtdIns $(3,4) \mathrm{P}_{2}$. The relative optical intensities (ROIs) for all the spots indicating the amount of protein bound to the phosphoinositides were recorded from Figure 20. Figure 21 shows that the binding of rPSP-V5 was maximum to $\operatorname{PtdIns}(3,4) \mathrm{P}_{2}$, followed by $\operatorname{PtdIns}(3,4) \mathrm{P}_{2}, \operatorname{PtdIns}(4,5) \mathrm{P}_{2}, \operatorname{PtdIns}(3,4,5) \mathrm{P}_{3}$ and there was no binding visible with PtdIns(3)P and PtdIns. This data shows rPSP directly bound to PtdIns(3,4)P2 as it is a purified protein. Also there being a selective binding of PSP to particular PtdInsPs, which must be mediated by interactions with the different headgroups of the lipids. The proteinlipid overlay assays were performed twice for both GST-rPSP-V5 and rPSP-V5. 
Figure 20: Phosphoinositide binding properties of rPSP-V5

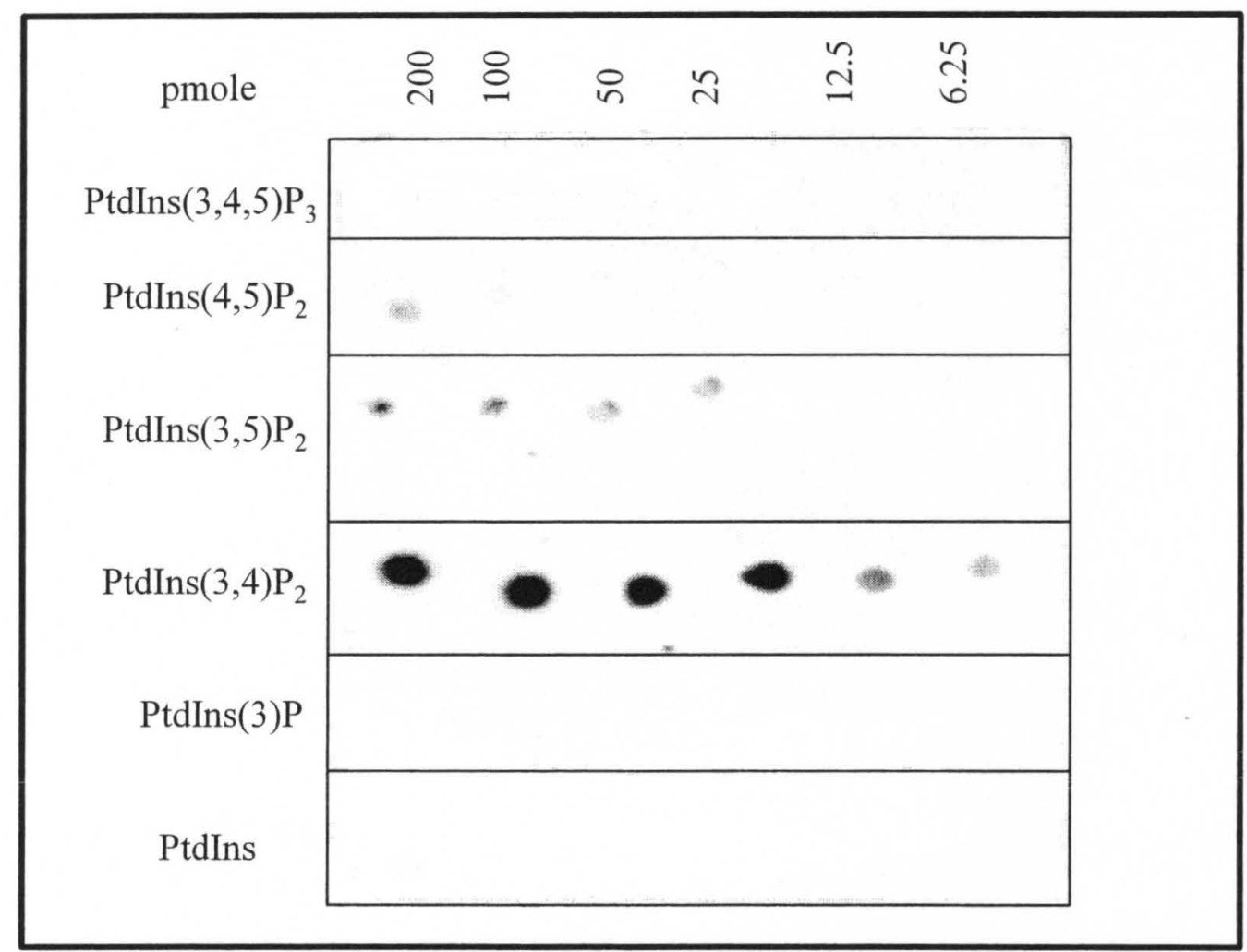

Figure 20: Lipid binding properties of rPSP-V5 were analysed by a protein-lipid overlay assay. $1 \mu \mathrm{g} / \mathrm{mL}$ of rPSP-V5 protein was incubated with the nitrocellulose membrane spotted with serial dilutions of different phosphoinositides. The membrane was washed in PBST and protein bound to lipid spots on membrane was detected by anti-V5 antibody. 
Figure 21: Relative Binding of rPSP-V5 to different Phosphoinositides

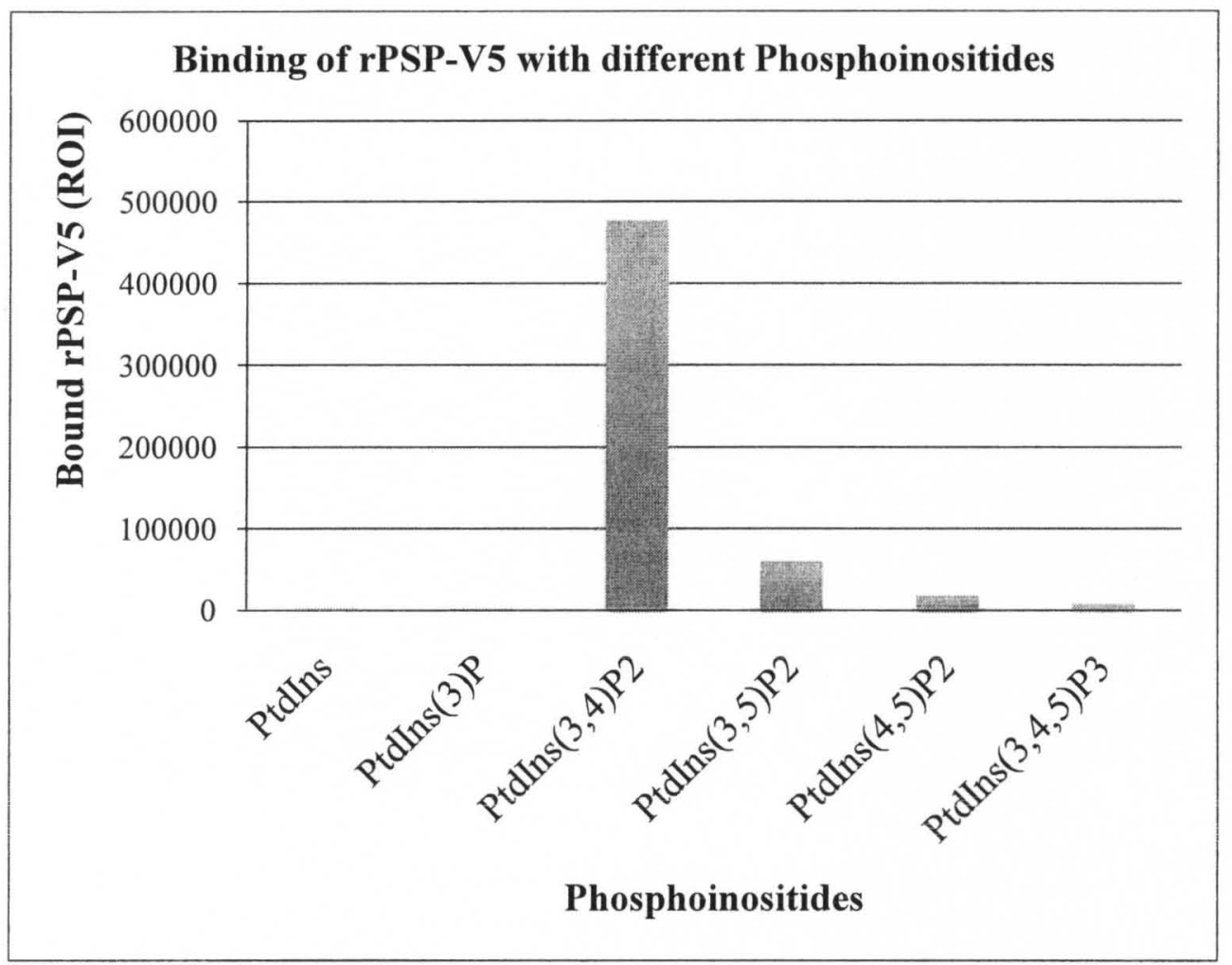

Figure 21: Relative optical intensities were recorded from the Protein-lipid overlay assay (Figure 20) using the Kodak imagestation and were plotted as a bar graph with the different phosphoinositides spotted on the nitrocellulose membrane. 
The above experiments demonstrated strong binding of rPSP-V5 to PtdIns $(3,4) \mathrm{P}_{2}$ compared to other PtdInsPs. A protein-lipid overlay assay was done for only PtdIns(3,4) $\mathrm{P}_{2}$ and PtdIns (Figure 22). Serial diltuions (200, 100, 50, 25, 12.5, $\left.6.25 \mathrm{pmol}\right)$ of both the lipids were spotted on a nitrocellulose membrane and incubated with $1 \mu \mathrm{g} / \mathrm{mL}$ of rPSP-V5. The relative optical intensities recorded from the bound protein were analysed on the Graph Pad Prism as binding curve. Figure 22 shows the binding curve which is representative of six experiments. These data suggest half maximal binding at less than $50 \mathrm{pmol}$ lipid, indicating strong binding. Further experiments were done to quantify the binding affinity of rPSP-V5 to $\operatorname{PtdIns}(3,4) \mathrm{P}_{2}$.

Quantify the Binding affinity $(\mathrm{Kd})$ of rPSP-V5 to $\operatorname{PtdIns}(3,4) \mathrm{P}_{2}$.

Different concentrations of rPSP-V5 ranging from $0.1 \mu \mathrm{g} / \mathrm{mL}$ to $3.5 \mu \mathrm{g} / \mathrm{mL}$ were incubated with nitrocellulose membrane spotted in duplicate with $50 \mathrm{pmol}$ of PtdIns $(3,4) \mathrm{P}_{2}$ and PtdIns. After 1 hour incubation, an aliquot of the incubation solution was taken to directly measure the free rPSP-V5 protein available. Free protein was spotted on the nitrocellulose membrane, and air dried. Bound rPSP-V5 on the membrane was washed, and quantified by probing with anti-V5 antibody. To create a standard curve for rPSP-V5, known amounts of rPSP-V5 (.00025 ug to 0.1ug) were spotted on a nitrocellulose membrane (Figure 23 B). rPSP on all the membranes was quantified by using anti-V5 antibody. Relative optical intensites of spots on all the membranes were recorded from the Kodak imagestation and the amount of free and bound protein was calculated using the standard curve (Figure $24 \mathrm{~B}$ ). A $_{\mathrm{d}}$ value was calculated using Graph Pad Prism version 5.01 using the equation $y=B_{\max } x X /(K d+X)$ where $B_{\max }$ is the maximal binding, and $K_{d}$ is the concentration of the ligand required for half - maximal 
binding. The binding curve (Figure $\mathbf{2 4} \mathbf{A}$ ) is a non linear regression fit using One SiteSpecific Binding as the parameter. $A K_{d}$ of $3 \times 10^{-11} \mathrm{M}$ was obtained, representing an average of three consecutive experiments. 
Figure 22: Protein-lipid overlay assay: Different concentration of $\operatorname{PtdIns}(3,4) \mathrm{P}_{2}$
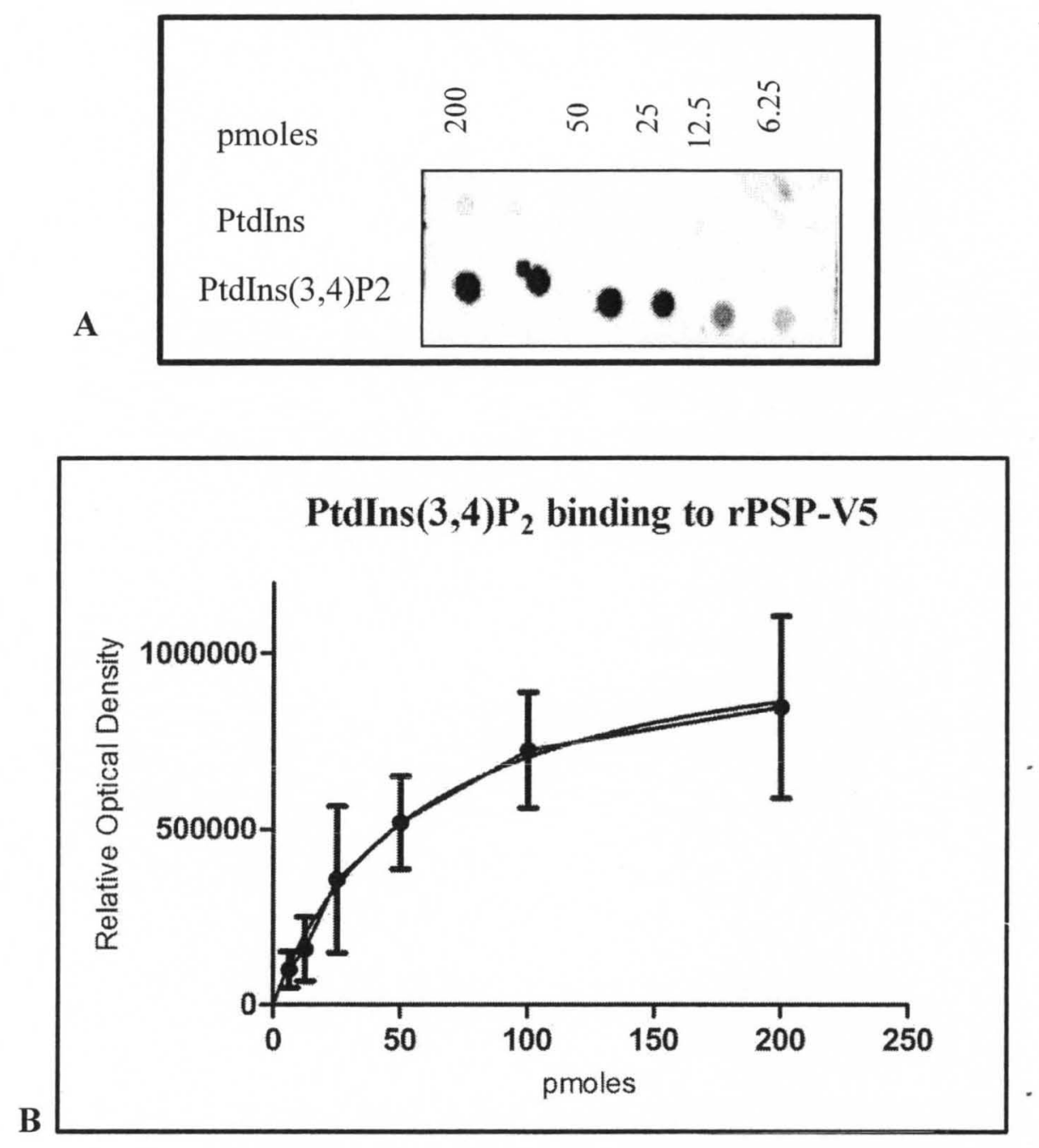

Figure 22: A: A protein-lipid overlay assay with serial dilution of $\operatorname{PtdIns}(3,4) \mathrm{P}_{2}$ and PtdIns. Protein bound to the membrane by interaction with lipid was detected by Anti-V5 antibody. ROIs were recorded on the Kodak imagestation and were analysed on Graph Pad Prism version 5.01. B: The Binding curve represents a non linear regression curve accounting for One Site- Specific Binding. 
Figure 23: Protein-lipid overlay assay: Different concentration of rPSP-V5
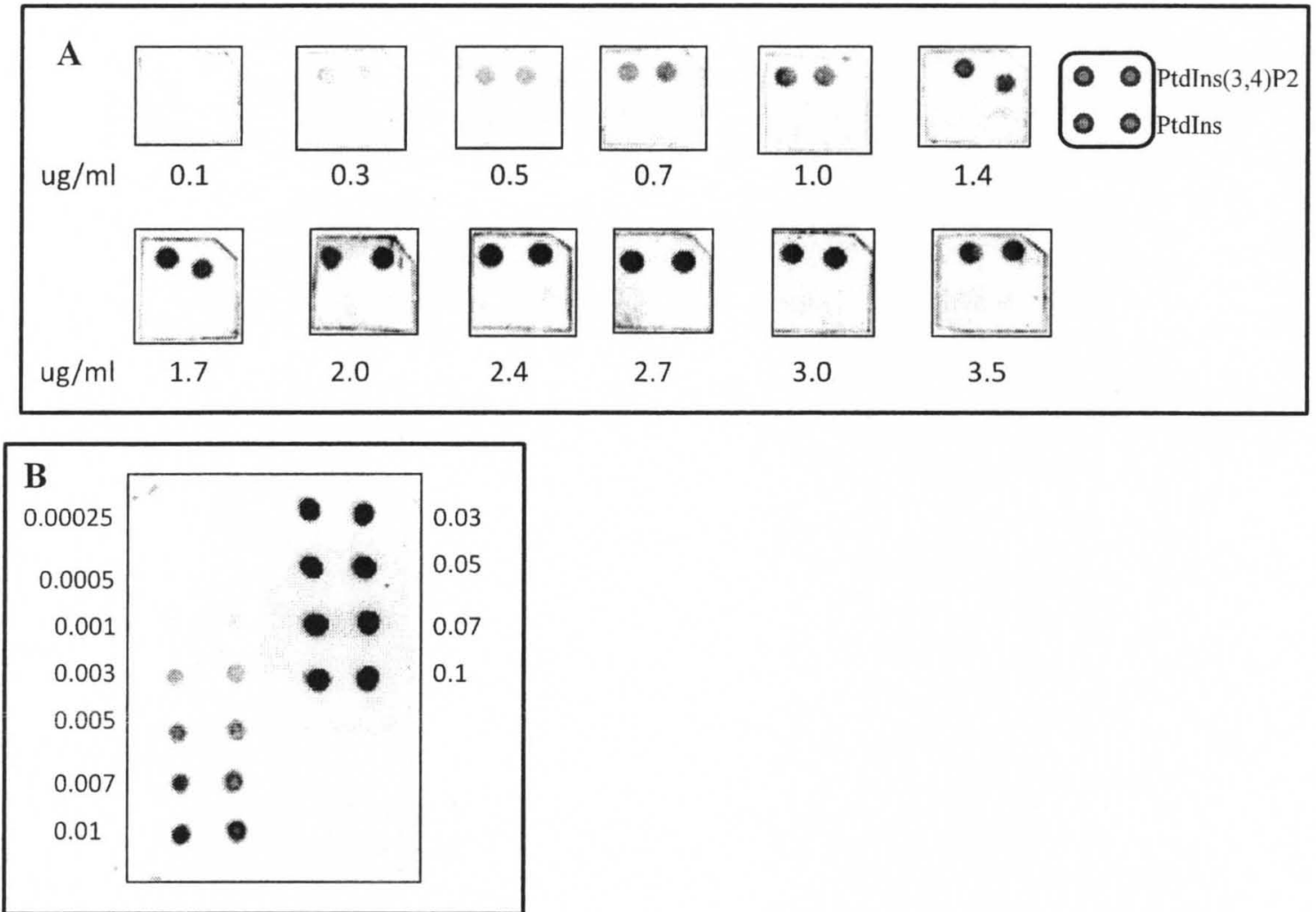

Figure 23: The PreScission protease eluted protein were incubated with the nitrocellulose membrane spotted with PtdIns $(3,4) \mathrm{P}_{2}$ and PtdIns $(50 \mathrm{pmol})$ in duplicates. B: Serial dilution of rPSP-V5 was spotted on the membrane for obtaining a standard curve. All the membranes were incubated with Anti-V5 HRP antibody (1:5000) dilution and their ROIs were recorded on the Kodak image station. 
Figure 24: Binding Curve for Ptdins $(3,4) \mathrm{P}_{2}$ binding to rPSP-V5

A

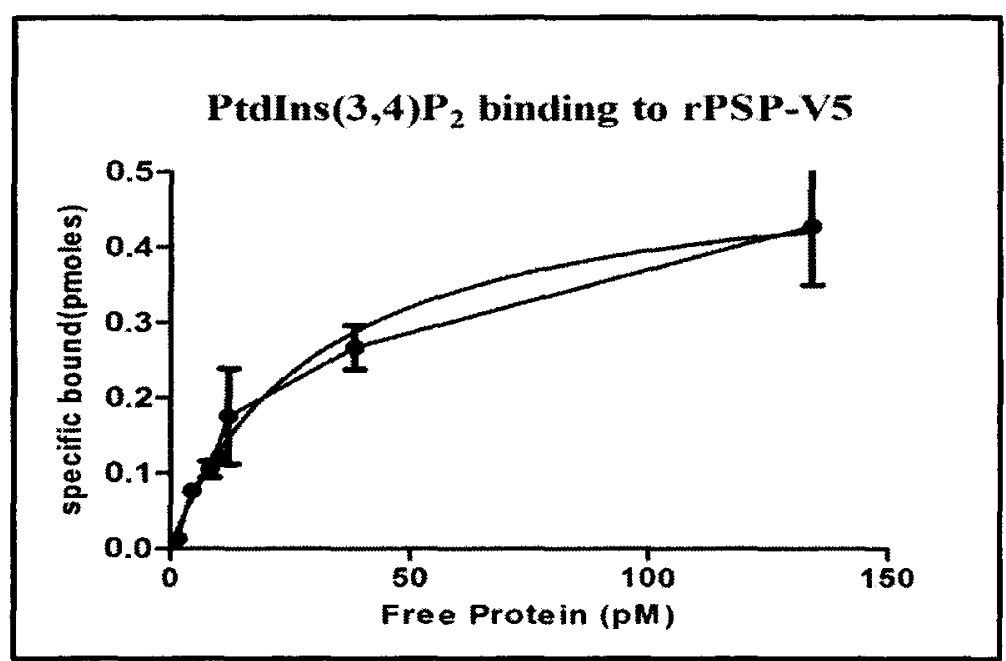

B

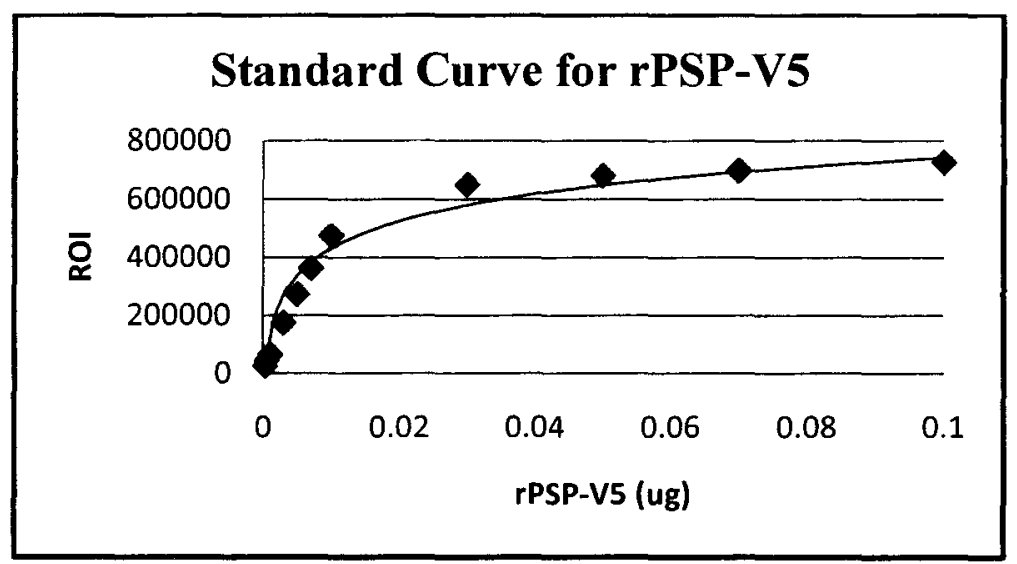

Figure 24: Different concentrations of protein were incubated with 50 pmol of

PtdIns $(3,4) \mathrm{P}_{2}$ and PtdIns. The data were obtained by measuring the relative optical intensity for each spot in figure 19, and specific bound protein and free protein were back calculated using the standard curve (B). The binding curve (A) has been derived using the equation $y=B_{\max } x X /\left(K_{d}+X\right)$ where $B_{\max }$ is the maximal binding and $K_{d}$ is the concentration of ligand required for half-maximal binding. 


\section{PURIFICATION AND BINDING OF p47 $7_{\text {phox }}$ to PtdIns(3,4) $\mathbf{P}_{2}$}

A well known PtdIns $(3,4) \mathrm{P}_{2}$ binding protein was used to directly compare its binding activity to rPSP. The reported affinity for $\mathrm{P} 47_{\text {phox }}$ is $2.6 \times 10^{-6} \mathrm{M}[34,40]$. The plasmid pGEX 4T-1-p47 phox (aa2-132) (Addgene) was transformed into BL-21 competent cells. Also the p47 phox $\mathrm{cDNA}$ was cloned into pGEX 6P-1 with a V5 tag (GST-2-p47 PhoxV5) added to it. Both GST-p47 $7_{\text {phox }}$ and GST-2-p47 $7_{\text {phox }}-\mathrm{V} 5$ were induced with $1.0 \mathrm{mM}$ IPTG for 5 hours at room temperature. The protein was purified using the same method used for GST-rPSP-V5 purification. Affinity purified glutathione eluted protein from GST-p47 phox was loaded on 4-12\% SDS-PAGE. Figure 25 (A1) is the western blot probed with anti-GST antibody (1:500) dilution. The $40 \mathrm{kDa}$ size band is GST-p47 $7_{\text {phox }}$. Figure 25 (A2) is the silver stained gel of the glutathione eluted protein showing a single protein. Therefore, the protein purification protocol optimized for rPSP was successful in purifying the GST-p47 $7_{\text {phox }}$ GST-2-p47 $7_{\text {phox }}-\mathrm{V} 5$ protein was affinity purified and cleaved with Prescission protease enzyme to obtain $\mathrm{p} 47_{\mathrm{phox}}-\mathrm{V} 5$ protein. To compare the binding of rPSP-V5 to GST-p47 $7_{\text {phox }}$, a protein-lipid overlay assay was done. Figure 25 B shows nitrocellulose membranes spotted with serial dilutions of $\operatorname{PtdIns}(3,4) \mathrm{P}_{2}$ and PtdIns. They were incubated with $3 \mu \mathrm{g} / \mathrm{mL}$ of GST -2-rPSP-V5 and GST-p47 phox $-\mathrm{V} 5$ fusion proteins. One membrane was incubated with GST-V5 alone (negative control). Binding of the protein to the lipid was detected by anti-GST antibody. The figure shows that GST$\mathrm{p} 47_{\text {phox }}$ does not bind as strongly to PtdIns $(3,4) \mathrm{P}_{2}$ as compared to GST-2-rPSP-V5. In another experiment, a very high concentration $(15 \mu \mathrm{g} / \mathrm{mL})$ of $\mathrm{p} 47 \mathrm{hox}-\mathrm{V} 5$ was incubated with the nitrocellulose membrane spotted with $50 \mathrm{pmol}$ of $\operatorname{PtdIns}(3,4) \mathrm{P}_{2}$. The membrane was probed with anti-V5 HRP antibody. 
Figure $25 \mathrm{C}$ shows that a higher concentration of GST-p47 phox bound to $\operatorname{PtdIns}(3,4) \mathrm{P}_{2}$ Thus it can be concluded that a rPSP-V5 binds strongly to the lipid as compared to $\mathrm{p} 47_{\text {phox }}$

\section{PURIFICATION AND BINDING OF GST-hPSP-V5 to PtdIns(3,4)P}

The Human PSP cDNA was cloned into pGEX 4T-3 expression vector and was tagged with V5. It was transformed into BL-21 cells. The method optimized for expression and purification of GST-rPSP-V5 was used for GST-hPSP-V5. The affinity purified and glutathione eluted protein was used for studying the binding to PtdIns .Nitrocellulose membrane were spotted with $100 \mathrm{pmol}$ of the following lipids- PtdIns, PtdIns $(3,4) \mathrm{P}_{2}, \mathrm{PtdIns}(3,5) \mathrm{P}_{2}$ and $\mathrm{PtdIns}(4,5) \mathrm{P}_{2}$. They were incubated with $1 \mu \mathrm{g} / \mathrm{mL}$ of GST-rPSP-V5, GST-hPPS-V5 fusion proteins. GST-V5 was used as a negative control. The membranes were probed with anti-V5 antibody and the binding signal was detected on the Kodak image station. Figure 26 shows that GST-hPSP-V5 bound to PtdIns $(3,4) \mathrm{P}_{2}$, but the relative optical intensity of the bound GST-hPSP-V5 protein was less than GSTrPSP-V5 bound protein P. GST-hPSP-V5 bound specifically to the phosphorylated forms of Phosphotidylinositol and no binding was seen with PtdIns. 
Figure 25: Purification and Binding of GST-p47phox
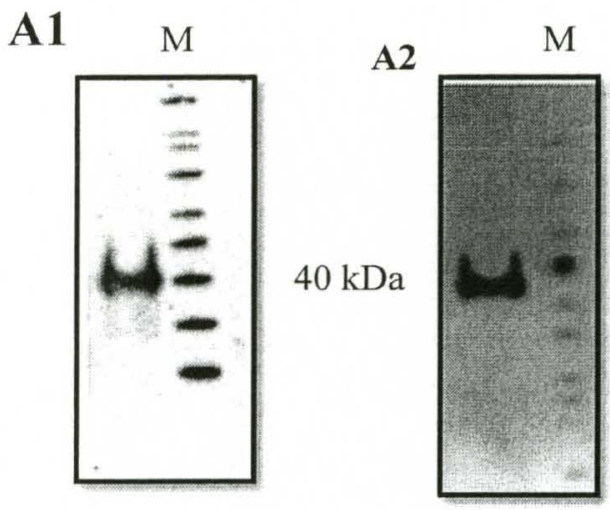

$$
\text { GST-p47 } 7_{\text {phox }}
$$

C

$$
\mathrm{p} 47_{\text {phox }}-\mathrm{V} 5
$$
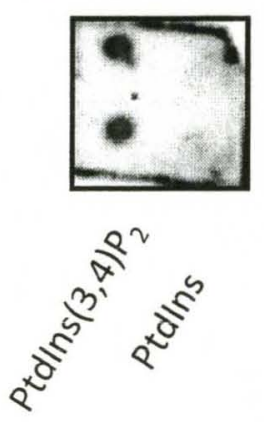

B

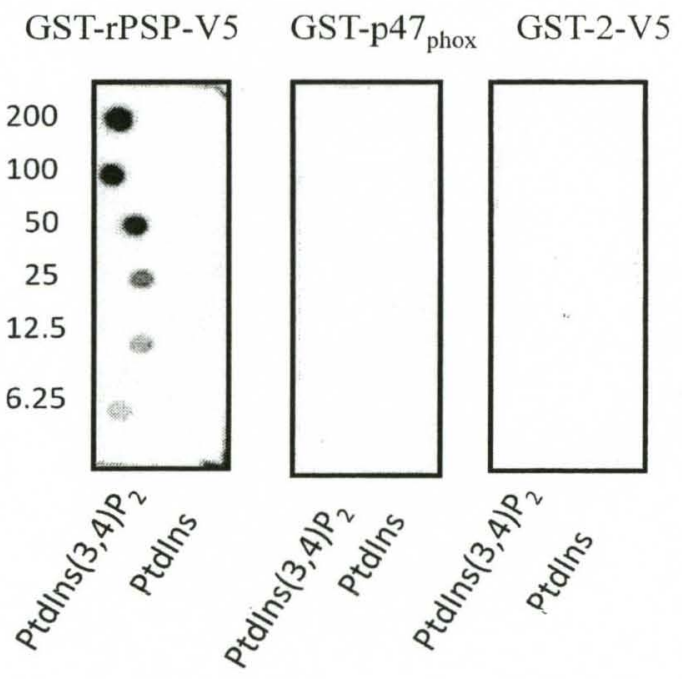

Figure 25 - 3ug of affinity purified and Glutathione eluted GST-p47 phox protein was loaded on the $4-12 \%$ SDS-PAGE. A1 is the western blot probed with anti-GST antibody (1:500) dilution, and A2 is the silver stained gel showing the purified GST-p47phox. B shows the protein-lipid overlay assay for GST-rPSP-V5, GST-p47 $7_{\text {phox }}$ and GST-V5. Binding of $3 \mu \mathrm{g} / \mathrm{mL}$ of the glutathione eluted protein incubated with nitrocellulose membrane was detected with anti-GST antibody. C shows binding of $15 \mu \mathrm{g} / \mathrm{mL}$ of $\mathrm{p} 47_{\text {phox }}-\mathrm{V} 5$ to PtdIns $(3,4) \mathrm{P}_{2}$ on a nitrocellulose membrane detected with anti-V5 HRP antibody. 
Figure 26: Binding of GST-hPSP-V5 to PtdIns $(3,4) \mathrm{P}_{2}$

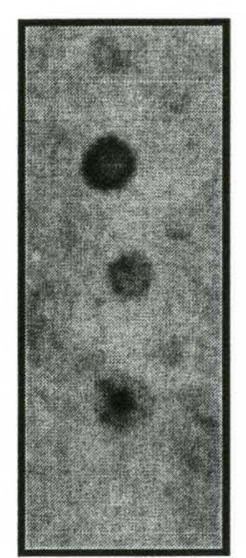

GST-hPSP-V5

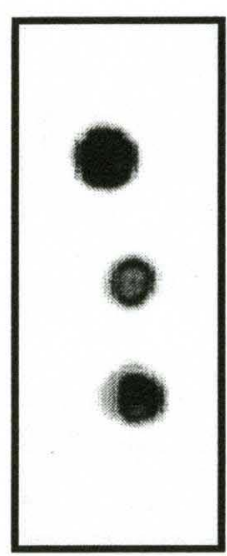

GST-rPSP-V5
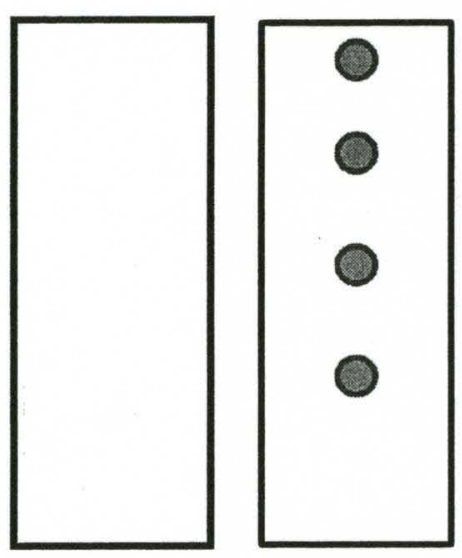

GST-V5
PtdIns

PtdIns $(3,4) \mathrm{P}_{2}$

PtdIns $(3,5) \mathrm{P}_{2}$

PtdIns $(4,5) \mathrm{P}_{2}$

Figure 26: $1 \mu \mathrm{g} / \mathrm{mL}$ of GST fused rPSPdss and hPSPdss were incubated with the nitrocellulose membrane spotted with different PtdInsPs (100 pmol). The binding of the protein to the lipid was detected by Anti-V5 antibody. GST-V5 was used as a negative control. 


\section{DISCUSSION}

\section{PAROTID SECRETORY PROTEIN}

Parotid Secretory Protein (PSP) is one of the most abundant proteins present in saliva secreted from rat parotid gland $[61,62]$. Rat PSP is the homologue of mouse PSP [63]. It is a $23 \mathrm{kDa}$ leucine rich protein $[64,65]$. It is present in immature acinar cells, seen as soon as the first postnatal week and increasing by 21 days to the high adult level $[62]$.

PSP is a member of the Palate Lung-Nasal epithelium clone (PLUNC) gene subfamily within the larger BPI family of mammalian proteins that include bactericidal permeability-increasing protein (BPI) and lipopolysaccharide-binding protein (LBP) [2]. BPI and LBP are two key members of the innate immune response to Gram negative bacteria. LBP and BPI are crucial in host defense against gram negative bacteria [66]. The amino acid sequences of Palate Lung-Nasal epithelium clone (PLUNC) protéins are similar BPI and LBP [66-68]. PLUNCs are largely expressed in the upper respiratory tract and oral cavity thereby serving a role in host defense [66-68]. The PLUNC family has been divided into short PLUNC (SPLUNC) and long PLUNC (LPLUNC) proteins. SPLUNC 2 is the human orthologue of rodent PSP with $22 \%$ similar and $52 \%$ identical protein sequence[69]. Like rat PSP, SPLUNC2 is expressed predominantly in parotid and submandibular glands. It has also been shown to be produced by minor salivary glands [69]. Its presence in whole saliva has been reported by many proteomic studies [70]. 
Thus considering its genomic location, sequence and expression patterns of SPLUNC 2, it is clear that this gene product is human PSP. Western analysis shows that multiple isoforms of SPLUNC2 (hPSP) are present in saliva. This could be due to differential glycosylation of the protein [69]. These multiple isoforms could exhibit different properties.

\section{PURIFICATION OF PROTEIN}

The initial goal for the thesis was to express and purify rat PSP in well known expression system, Escherichia coli (E.coli) [71, 72]. rPSP was first made into a cDNA fusion clone with an affinity tag (Glutathione-S-transferase) present in the pGEX'vector. Affinity tags can increase the yield of protein [73], increase the protein solubility [74], help in purifying the protein [75], and decrease proteolysis of protein. There are several fusion tags available, including polyhistidine tags [76], FLAG tags [77], thioredoxin, Protein A, strep tag and maltose binding protein [76]. Glutathione-S-transferase [53] has been widely used as a fusion tag for protein expressed in E.coli. The rPSP cDNA was inserted into pGEX vector system containing the GST tag. Two expression vectors pGEX $4 \mathrm{~T}$ and pGEX $6 \mathrm{P}-1$ were tested for the expression and purification of protein. The protein purification protocol was first optimized for rPSP inserted into pGEX 4T-3 vector. An epitope tag (V5) was included at the end of PSP to provide an easy way to detect the expressed protein. Protein induction was carried out with $0.1 \mathrm{mM} \mathrm{IPTG.}$

Glutathione-S-transferase is a $26 \mathrm{kDa}$ protein [57] and the expressed GST-rPSP-V5 fusion protein is a $50 \mathrm{kDa}$ protein. On analyzing the western blot probed with anti-V5 antibody the correct band size of protein was seen (Figures 5, 6). Often protein expressed 
in bacteria is insoluble and is seen present as inclusion bodies [78, 79]. Inclusion bodies contain insoluble aggregates of the recombinant protein. Ionic and non -ionic detergents have been shown to solubilize certain proteins into the supernatant without affecting binding to the glutathione beads [54]. Adding as little as $0.25 \%$ sarkosyl to the cell lysis buffer was able to completely solubilize one GST fused protein [55]. Different concentrations of sarkosyl were tested, and $0.25 \%$ sarkosyl was the lowest concentration which was able to solubilize the GST-PSP fusion (Figures 18, 19). pGEX expression vectors have specific protease cleavage sites incorporated in them. A thrombin cleavage site is encoded in the pGEX 4T vectors to enable the separation of the GST tag from the fused protein. Several experiments were performed to optimize the cleavage conditions but these were not successful in cleaving the GST tag from rPSP without allowing degradation of the PSP (Figure 14). This led to cloning rPSP cDNA into a different expression vector pGEX 6P, which has a PreScission protease cleavage site. Several changes were made in the protein purification protocol. To reduce the low molecular weight impurities, the induction temperature of the plasmid pGEX 6P-1-rPSPdss-attB was reduced from $37^{\circ} \mathrm{C}$ to room temperature as it increased the stability of the fusion protein (Figure 18) [80]. When the protein was eluted from the glutathione beads, and analysed on SDS-PAGE by silver staining, a $70 \mathrm{kDa}$ contaminant was observed which was identified as the chaperone protein Dnak. It has been observed that Dnak (an abundant protein in E.coli, about 1\%) [81] often binds to the connecting peptide regions and copurifies with the fusion protein. These biological impurities can interfere with the future studies involving the protein. Dnak contamination was minimized by washing the protein bound to beads with MgATP [58, 82] and denatured E.coli protein [58]. When 
Dnak is bound to ATP its affinity for the protein decreases [83]. After incubating the GST-rPSP-V5 lysate with the glutathione-Sepharose bead, the beads were washed three times with ATP, $\mathrm{MgSO}_{4}$ and denatured E.coli protein, followed by incubating the beads with the elution buffer (Figure 17).

It was then required to cleave the rPSP cDNA insert from the GST tag. As the pGEX 6P-1 expression vector are engineered with a PreScission Protease cleavage site, the PreScission enzyme was added to the binding reaction. $10 \mathrm{U}$ of the enzyme for every $0.1 \mathrm{~mL}$ of glutathione epahrose column was sufficient to remove the GST tag (Figure 19). The concentration of the rPSP-V5protein obtained after cleavage was $90 \mu \mathrm{g} / \mathrm{mL}$.

\section{PSP BINDS SPECIFICALLY TO PtdIns(3,4)P 2 WITH A HIGH AFFINITY}

Binding studies were done using GST-rPSP-V5 and rPSP-V5 alone. Both of these expressed rPSP proteins showed strong binding to $\operatorname{PtdIns}(3,4) \mathrm{P}_{2}$. GST-V5 alone did not show binding to either PtdInsPs or to PtdIns suggesting that the binding was specific for rPSP. From the protein overlay experiments where binding to all PtdInsPs were tested (Figure 20), we observed a 10-fold higher binding of rPSP to $\operatorname{PtdIns}(3,4) \mathrm{P}_{2}$ compared to $\operatorname{PtdIns}(3,5) \mathrm{P}_{2}$ or PtdIns $(4,5) \mathrm{P}_{2}$ and minimal binding to $\operatorname{PtdIns(3)P~(Figure~21).~}$ Maximum binding was seen with PtdIns( $(3,4) \mathrm{P}_{2}$ followed by $\operatorname{PtdIns}(3,5), \operatorname{PtdIns}(4,5)$ and PtdIns $(3,4,5) \mathrm{P}_{3}$ in decreasing order. There was no binding observed to unphosphorylated PtdIns. This suggests that PSP specifically binds to $\operatorname{PtdIns}(3,4) \mathrm{P}_{2}$. This also shows that PSP interacts with inositol head group since identical lipid chains are present in PtdIns (which is not bound) as in $\operatorname{PtdIns}(3,4) \mathrm{P}_{2}$ (which is bound by PSP). The virtual absence of PSP binding to $\operatorname{PtdIns}(3,4,5) \mathrm{P}_{3}$ or to $\mathrm{Ptd} \operatorname{Ins}(4,5) \mathrm{P}_{2}$ shows that the interaction is NOT due 
to non-specific inonic interactions with the charged phosphate groups. This binding supports the hypothesis that PSP binds directly to $\operatorname{PtdIns}(3,4) \mathrm{P}_{2}$ since this was a relatively purified preparations of $\mathrm{rPSP}-\mathrm{V} 5$, and no other mammalian proteins were present.

On testing the binding to different amounts of lipids, it was seen that PSP-V5 bound to as little as $6.25 \mathrm{pmol}$ of $\operatorname{PtdIns}(3,4) \mathrm{P}_{2}$ (Figure 20) which is consistent with other PtdIns(3,4) $\mathrm{P}_{2}$ binding proteins like TAPP1 and p47 phox $[37,40]$ listed in Table 2. These proteins bind to PtdIns $(3,4) \mathrm{P}_{2}$ through specific lipid binding domains like $\mathrm{PH}$ or $\mathrm{PX}$. The $\mathrm{pH}$ for all the binding experiments was kept constant at 7.0 and rPSP bound specifically to $\mathrm{PtdIns}(3,4) \mathrm{P}_{2}$ at this $\mathrm{pH}$. In the parotid gland, the $\mathrm{pH}$ of the granule increases from $\mathrm{pH} 6.0$ at trans-Golgi network to above $\mathrm{pH} 6.8$ after maturation [84]. Thus interaction of $\mathrm{rPSP}$ to $\mathrm{PtdIns}(3,4) \mathrm{P}_{2}$ at this $\mathrm{pH}$ range is consistent with binding in vivo.

Binding studies with human PSP showed specific binding for $\operatorname{PtdIns}(3,4) \mathrm{P}_{2}$ but with weaker binding when compared to rPSP (Figure 26 ). Human PSP did not bind to unphosphorylated PtdIns, but did bind strongly to PtdIns $(3,4) \mathrm{P}_{2}$. There was distinctly less binding to PtdIns $(3,5) \mathrm{P}_{2}$ and PtdIns $(4,5) \mathrm{P}_{2}$. The sequence of human PSP is onlt $52 \%$ identical to rat PSP (Figure 27). This low level of similarity would suggest that the structures of rat and hyman PSPs have diverged duting evolutions, yet we find that both human PSP and rat PSP bind to $\operatorname{PtdIns}(3,4) \mathrm{P}_{2}$ specifically. This is the first demonstration of Human PSP binding to phospholipids. This demonstrates the conservations of function between rat and human PSP.

Protein-lipid overlay assays were used to estimate the binding affinity $\left(\mathrm{K}_{\mathrm{d}}\right)$ of rPSP for PtdIns $(3,4) \mathrm{P}_{2}$. Incubations were done with a broad range of concentrations of 
rPSP-V5. The amounts of bound and free protein were directly measured and the data was analysed on Graph Pad prism software version 5.01. The Binding affinity $\left(\mathrm{K}_{\mathrm{d}}\right)$ was calculated, using a non-linear regression curve fit and the data was analyzed for One site Specific Binding (Figure 24). In three consecutive experiments, the calculated affinities ranged from $1.85 \times 10^{-10}$ to $3 \times 10^{-11} \mathrm{M}$ (Table 4). The $\mathrm{K}_{\mathrm{d}}$ value determined for rPSP-V5 (30 pM) using the lipid overlay assay indicates stronger binding than the $K_{d}$ values reported for two other PtdIns(3,4) $\mathrm{P}_{2}$ specific binding proteins: $\mathrm{p} 47_{\text {phox }}(2.6 \mathrm{uM})$ and TAPP1 (1.5 nM) (Table 3). Thus, these values suggest that PSP is a higher affinity protein. 
Figure 27: Amino acid sequence comparison of rPSP and hPSP

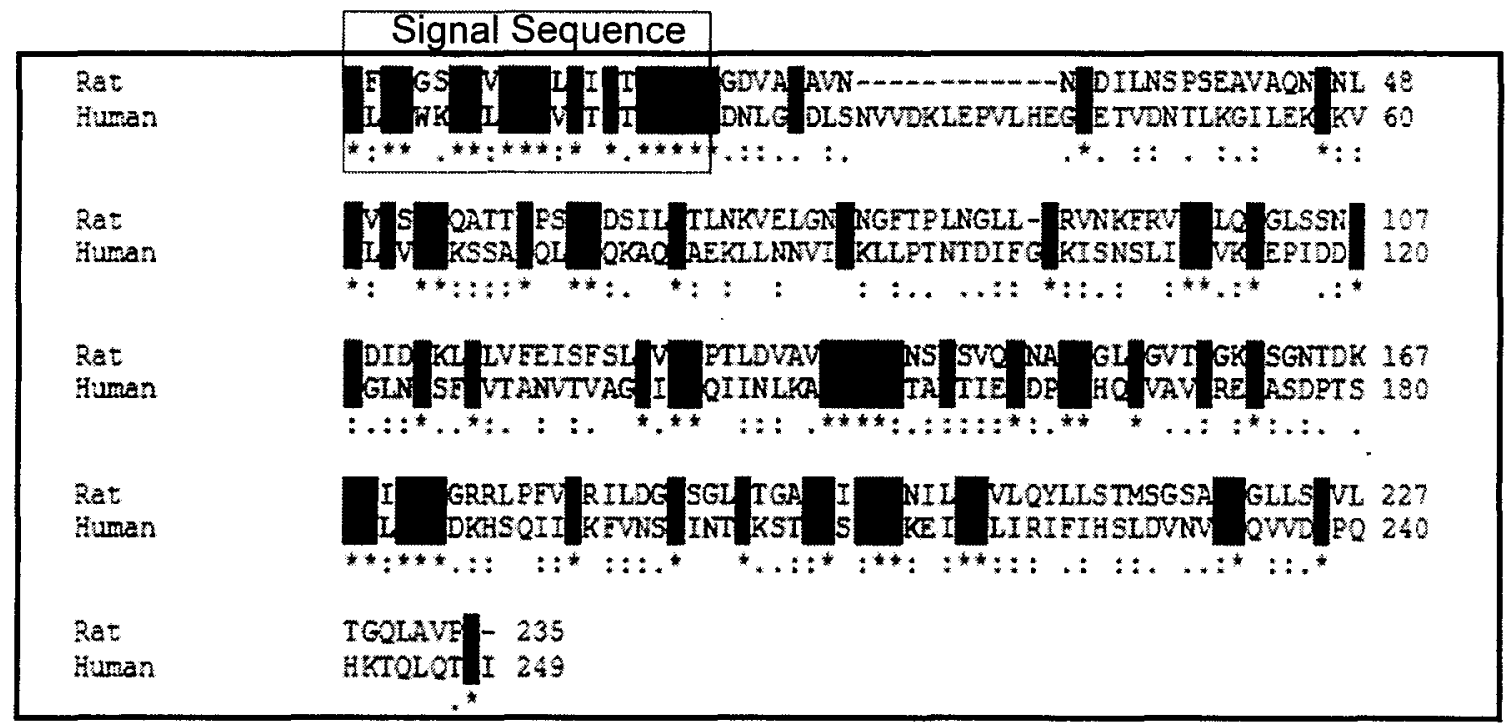

Figure 27: The amino acid identity between rat and human PSPs is very low. Identical amino acids are highlighted in red. Basic amino acids $(\mathrm{R}, \mathrm{K})$ which allow binding to PtdInsPs are not conserved. Therefore, it seemed unlikely that human PSP could bind membrane phospholipids as observed with rat PSP. 
This data supports our theory that binding of PSP to the PtdIns $(3,4) \mathrm{P}_{2}$ present at the vesicle membrane could act as a sorting signal and lead to sorting of PSP into the vesicle.

We included GST-p47 phox in our binding studies. P47 phox is a PX domain protein binding specifically to $\operatorname{Ptd} \operatorname{Ins}(3,4) \mathrm{P}_{2}$. PX domains are specific phosphoinositide-binding modules, with different PX domains having different phosphoinositide specificity. It has been suggested that binding of $\mathrm{p} 47_{\text {phox }}$ to $\operatorname{PtdIns}(3,4) \mathrm{P}_{2}$ in the membrane leads to NADPH oxidase activation which plays an important role in host defense mechanism of neutrophils and macrophages $[34,40,85]$. The binding affinities of the two proteins were compared using the protein-lipid overlay assay. The experiments (Figure 25 B) showed strong binding of GST-2-rPSP-V5 $(3 \mu \mathrm{g} / \mathrm{mL})$ to PtdIns $(3,4) \mathrm{P}_{2}$ and very weak binding of GST-p47 phox $(3 \mu \mathrm{g} / \mathrm{mL})$ to $\operatorname{PtdIns}(3,4) \mathrm{P}_{2} .15 \mu \mathrm{g} / \mathrm{mL}$ of $\mathrm{p} 47_{\text {phox }}-\mathrm{V} 5$ bound to PtdIns $(3,4) \mathrm{P}_{2},($ Figure 25C), suggesting that a higher concentration of protein was required for binding. The reported $\mathrm{Kd}$ value for $\mathrm{p} 47_{\text {phox }}\left(3.8 \times 10^{-8} \mathrm{M}\right)$ is more than the estimated $K_{d}$ value for $\operatorname{rPSP}\left(3.0 \times 10^{-11} \mathrm{M}\right)$. Therefore GST-p $47_{\text {phox }}$ does bind to $\operatorname{PtdIns}(3,4) \mathrm{P}_{2}$ but with a lower affinity as compared to GST-rPSP.

PtdIns $(3,4) \mathrm{P}_{2}$ is a minor phosphoinositide, comprising only $0.2 \%$ of total PtdIns $\mathrm{P}_{2}[86]$. Its interaction with lipid binding proteins mediates an important role in signaling cascades. PtdIns $(3,4) \mathrm{P}_{2}$ is present on the plasma membrane being produced mainly by dephosphorylation of PtdIns(3,4,5) $\mathrm{P}_{3}$ by action of 5-phosphatases [31].[42]. An important mediator of insulin signaling, $\mathrm{PKB}$ (protein kinase $\mathrm{B}$ )/Akt binds to PtdIns(3,4) $\mathrm{P}_{2}$ via its $\mathrm{PH}$ domain[28, 87]. 
Table 2: Specific PtdIns(3,4) $\mathbf{P}_{2}$ binding proteins

\begin{tabular}{|c|c|c|}
\hline PROTEIN & DOMAIN & REF \\
\hline TAPP1, TAPP2 & PH & {$[33,37,41-43]$} \\
\hline DAPP1 & PH & {$[41]$} \\
\hline P47 $7_{\text {phox }}$ & PX & {$[38.39]$} \\
\hline
\end{tabular}

Table 3: Reported $K_{d}$ values of lipid binding proteins

\begin{tabular}{|c|c|c|c|}
\hline LIPID & PROTEIN & $\operatorname{AFFINITY}(\mathbf{M})$ & REF \\
\hline $\mathrm{PI}(4,5) \mathrm{P}_{2}$ & Phospholipase $\mathrm{C}-\delta 3$ & $7.7 \times 10^{-5}$ & {$[88]$} \\
\hline $\mathrm{PI}(3,45) \mathrm{P}_{3}$ & GAP1 & $9 \times 10^{-6}$ & [89] \\
\hline $\operatorname{PtdIns}(3,4,5) \mathrm{P}_{3}$ & GRP1 & $2.8 \times 10^{-8}$ & [90] \\
\hline PtdIns $(4,5) \mathrm{P}_{2}$ & Dynamin 1 & $9 \times 10^{-6}$ & [91] \\
\hline $\operatorname{Ptd} \operatorname{Ins}(3,4,5) \mathrm{P}_{3}$ & BtK-PH & $8 \times 10^{-8}$ & [92] \\
\hline$\overline{P t d I n s}(3,4) \mathrm{P}_{2}$ & Akt-PH & $3.5 \times 10^{-7}$ & {$[92]$} \\
\hline $\mathrm{Ptd} \operatorname{Ins}(3,4) \mathrm{P}_{2}$ & DAPP1 & $2.7 \times 10^{-7}$ & {$[92]$} \\
\hline$\overline{P t d I n s}(3,4) \mathrm{P}_{2}$ & $\mathrm{p} 47_{\text {phox }}$ & $3.8 \times 10^{-8}$ & {$[40]$} \\
\hline $\operatorname{PtdIns}(3,4) \mathrm{P}_{2}$ & TAPP1 & $5 \times 10^{-9}$ & {$[37]$} \\
\hline
\end{tabular}

Table 4: Estimated $K_{d}$ valued for rPSP

\begin{tabular}{|c|c|c|}
\hline EXPERIMENT NO. & $\mathbf{K}_{\mathrm{d}}(\mathbf{M})$ & $\mathbf{R}^{2}$ \\
\hline 1. & $3.03 \times 10^{-11}$ & .9400 \\
\hline 2. & $3.98 \times 10^{-11}$ & .9982 \\
\hline 3. & $1.85 \times 10^{-10}$ & .9938 \\
\hline
\end{tabular}

$$
\text { Average } K_{d}=2.4 \times 10-{ }^{11} M
$$


TAPP1(tandem-Ph-repeat-containing protein-1) binds to $\operatorname{PtdIns}(3,4) \mathrm{P}_{2}$ with its PH domain and its narrow specificity for PtdIns $(3,4) \mathrm{P}_{2}$ leads to the translocation of the protein to the plasma membrane [41]. PtdIns $(3,4) \mathrm{P}_{2}$ has been shown to play an important role in NADPH oxidase activation. TAPP1 and p47 phox interact with the $\mathrm{PO}_{4}$ groups on PtdIns $(3,4) \mathrm{P}_{2}$ through basic amino acids $(\mathrm{R}, \mathrm{K})$. PSP has $\mathrm{R} \& \mathrm{~K}$, which may allow the observed binding to PIP.

\section{CONCLUSIONS:}

Purified rat PSP showed strong binding with phosphatidylinositol- $(3,4)$ bisphosphate. Our results strongly suggest direct binding of the PSP to phospholipids since bacterially expressed and affinity purified protein was used. The extent of PSP binding is similar to results with TAPP1 and $\mathrm{p} 47_{\text {phox }}$, which are well characterized PtdIns $(3,4) \mathrm{P}_{2}$-binding proteins. The $\mathrm{K}_{d}$ value $(30 \mathrm{pM})$ estimated for $\mathrm{PPSP}$ shows that it has a high binding affinity for $\operatorname{PtdIns}(3,4) \mathrm{P}_{2}$. These results suggest that the observed binding of rat PSP to granule membranes may be by a direct interaction with $\operatorname{PtdIns}(3,4) \mathrm{P}_{2}$.

We demonstrate for the first time that human PSP binds to the headgroup of PtdIns $(3,4) \mathrm{P}_{2}$. The sequence of human PSP is not similar to rat PSP, yet we find that human PSP does bind PtdIns $(3,4) \mathrm{P}_{2}$ specifically. This is the first demonstration of Human PSP binding to phospholipids stating that the binding of $r P S P$ to $\operatorname{PtdIns}(3,4) \mathrm{P}_{2}$ is an important function which has been conserved in humans. 


\section{REFERENCES}

1. Gorr, S.-U., S.G. Venkatesh, and D.S. Darling, Parotid Secretory Granules: Crossroads of Secretory Pathways and Protein Storage. Journal of Dental Research, 2005. 84(6): p. 500-509.

2. Geetha, C., Expression and anti-bacterial activity of human parotid secretory protein (PSP). Biochem. Soc. Trans., 2003. 31(Pt 4): p. 815-818.

3. Geetha, C., Design and Validation of Anti-inflammatory Peptides from Human Parotid Secretory Protein. Journal of Dental Research, 2005. 84(2): p. 149-153.

4. Khovidhunkit, W., et al., Parotid secretory protein is an HDL-associated protein with anticandidal activity. Am J Physiol Regul Integr Comp Physiol, 2005. 288(5): p. R13061315.

5. Hammi, A.R., Assessment of SS-A and SS-B in parotid saliva of patients with Siögren's syndrome. Journal of Oral Pathology \& Medicine, 2005. 34(4): p. 198-203.

6. Chambers, M.S., et al., Radiation-induced Xerostomia in patients with head and neck cancer: Pathogenesis, impact on quality of life, and management. Head \& Neck, 2004. 26(9): p. 796-807.

7. Mathews, S.A., B.T. Kurien, and R.H. Scofield, Oral Manifestations of Sjögren's Syndrome. Journal of Dental Research, 2008. 87(4): p. 308-318.

8. Atkinson, J.C., M. Grisius, and W. Massey, Salivary Hypofunction and Xerostomia: Diagnosis and Treatment. Dental Clinics of North America, 2005. 49(2): p. 309-326.

9. Dikeakos, J.D. and T.L. Reudelhuber, Sending proteins to dense core secretory granules: still a lot to sort out. The Journal of Cell Biology, 2007. 177(2): p. 191-196.

10. Dannies, P.S., Concentrating hormones into secretory granules: layers of control. Molecular and Cellular Endocrinology, 2001. 177(1-2): p. 87-93.

11. Castle, D. and A. Castle, Intracellular Transport and Secretion of Salivary Proteins. Critical Reviews in Oral Biology \& Medicine, 1998. 9(1): p. 4-22.

12. Venkatesh, S.G., Isoproterenol increases sorting of parotid gland cargo proteins to the basolateral pathway. Am J Physiol Cell Physiol, 2007. 293(2): p. C558-565.

13. Lam, P.P.L., Alcohol Redirects CCK-Mediated Apical Exocytosis to the Acinar Basolateral Membrane in Alcoholic Pancreatitis. Traffic, 2007. 8(5): p. 605-617.

14. Dannies, P.S., Protein Hormone Storage in Secretory Granules: Mechanisms for Concentration and Sorting. Endocr Rev, 1999. 20(1): p. 3-21.

15. Arvan, P. and D. Castle, Sorting and storage during secretory granule biogenesis: looking backward and looking forward. Biochem. J., 1998. 332(3): p. 593-610.

16. Kelly, R., Pathways of protein secretion in eukaryotes. Science, 1985. 230(4721): p. 2532.

17. Brunner, Y., Proteomics of regulated secretory organelles. Mass Spectrometry Reviews, 2009. 28(5): p. 844-867.

18. Jackson, C.L., Mechanisms of transport through the Golgi complex. J Cell Sci, 2009. 122(4): p. 443-452. 
19. Venkatesh, S.G., D.J. Cowley, and S.-U. Gorr, Differential aggregation properties of secretory proteins that are stored in exocrine secretory granules of the pancreas and parotid glands. Am J Physiol Cell Physiol, 2004. 286(2): p. C365-371.

20. Park, J.J. and Y.P. Loh, Minireview: How Peptide Hormone Vesicles Are Transported to the Secretion Site for Exocytosis. Mol Endocrinol, 2008. 22(12): p. 2583-2595.

21. Arvan, P. and P.A. Halban, Sorting Ourselves Out: Seeking Consensus on Trafficking in the Beta-Cell. Traffic, 2004. 5(1): p. 53-61.

22. Blázquez M, S.K., Basic mechanisms of secretion: sorting into the regulated secretory pathway. biochem cell biology, 2000. 78(3).

23. Hosaka, M., et al., Identification of a Chromogranin A Domain That Mediates Binding to Secretogranin III and Targeting to Secretory Granules in Pituitary Cells and Pancreatic beta -Cells. Mol. Biol. Cell, 2002. 13(10): p. 3388-3399.

24. Jain, R.K., et al., In vitro aggregation of the regulated secretory protein chromogranin $A$. Biochem. J., 2002. 368(2): p. 605-610.

25. Lebel, D., G. Grondin, and J. Paquette, In vitro stability of pancreatic zymogen granules: roles of $\mathrm{pH}$ and calcium. Biology of the Cell, 1988. 63(3): p. 343-353.

26. Flashner, $Y$. and $M$. Schramm, Retention of amylase in the secretory granules of parotid gland after extensive release of $\mathrm{Ca}++$ by ionophore A-23187. The Journal of Cell Biology, 1977. 74(3): p. 789-793.

27. Greg Odorizzi, Phosphoinositide signalling and the regulation of membrane trafficking in yeast. Trends in Biotchemical Sciences, 2000. 25.

28. Lemmon, M.A., Membrane recognition by phospholipid-binding domains. Nat Rev Mol Cell Biol, 2008. 9(2): p. 99-111.

29. CZech, M.P., DYNAMICS OF PHOSPHOINOSITIDES IN MEMBRANE RETRIEVAL AND INSERTION. Annual Review of Physiology, 2003. 65(1): p. 791-815.

30. Kutateladze, T.G., Phosphatidylinositol 3-phosphate recognition and membrane docking by the FYVE domain. Biochimica et Biophysica Acta (BBA) - Molecular and Cell Biology of Lipids, 2006. 1761(8): p. 868-877.

31. Di Paolo, G. and P. De Camilli, Phosphoinositides in cell regulation and membrane dynamics. Nature, 2006. 443(7112): p. 651-657.

32. Odorizzi, G., M. Babst, and S.D. Emr, Phosphoinositide signaling and the regulation of membrane trafficking in yeast. Trends in Biochemical Sciences, 2000. 25(5): p. 229-235.

33. Cheever, M.L., et al., Phox domain interaction with Ptdins(3)P targets the Vam 7 t-SNARE to vacuole membranes. Nat Cell Biol, 2001. 3(7): p. 613-618.

34. Kanai, F., et al., The PX domains of $p 47$ phox and p40phox bind to lipid products of $P I(3) K$. Nat Cell Biol, 2001. 3(7): p. 675-8.

35. Simonsen, A. and H. Stenmark, PX domains: attracted by phosphoinositides. Nat Cell Biol, 2001. 3(8): p. E179-E182.

36. Sato, T.K., M. Overduin, and S.D. Emr, Location, Location, Location: Membrane Targeting Directed by PX Domains. Science, 2001. 294(5548): p. 1881-1885.

37. Dowler, S., et al., Identification of pleckstrin-homology-domain-containing proteins with novel phosphoinositide-binding specificities. Biochem. J., 2000. 351(1): p. 19-31.

38. Kutateladze, T. and M. Overduin, Structural Mechanism of Endosome Docking by the FYVE Domain. Science, 2001. 291(5509): p. 1793-1796.

39. Itoh, T., et al., Role of the ENTH Domain in Phosphatidylinositol-4,5-Bisphosphate Binding and Endocytosis. Science, 2001. 291(5506): p. 1047-1051. 
40. Karathanassis, D., et al., Binding of the PX domain of $p 47$ phox to phosphatidylinositol 3,4-bisphosphate and phosphatidic acid is masked by an intramolecular interaction. EMBO J, 2002. 21(19): p. 5057-5068.

41. Kimber, W.A., Evidence that the tandem-pleckstrin-homology-domain-containing protein TAPP1 interacts with Ptd $(3,4) P 2$ and the multi-PDZ-domain-containing protein MUPP1 in vivo. Biochem. J., 2002. 361(3): p. 525-536.

42. Watt, S.A., Detection of novel intracellular agonist responsive pools of phosphatidylinositol 3,4-bisphosphate using the TAPP1 pleckstrin homology domain in immunoelectron microscopy. Biochem. J., 2004. 377(3): p. 653-663.

43. Kimber, W.A., et al., Interaction of the protein tyrosine phosphatase PTPL1 with the Ptdins(3,4)P2-binding adaptor protein TAPP1. Biochem. J., 2003. 376(2): p. 525-535.

44. Hogan, A., The Phosphoinositol 3,4-Bisphosphate-binding Protein TAPP1 Interacts with Syntrophins and Regulates Actin Cytoskeletal Organization. Journal of Biological Chemistry, 2004. 279(51): p. 53717-53724.

45. Noack, D., Autosomal recessive chronic granulomatous disease caused by defects in NCF1 , the gene encoding the phagocyte p47-phox: mutations not arising in the NCF-1 pseudogenes. Blood, 2001. 97(1): p. 305-311.

46. Halstead, J.R., K. Jalink, and N. Divecha, An emerging role for Ptdlns(4,5)P2-mediated signalling in human disease. Trends in Pharmacological Sciences, 2005. 26(12): p. 654660.

47. Overduin, M., M.L. Cheever, and T.G. Kutateladze, Signaling with Phosphoinositides: Better than Binary. Molecular Interventions, 2001. 1(3): p. 150-159.

48. Baum, B.J., A. Voutetakis, and J. Wang, Salivary glands: novel target sites for gene therapeutics. Trends in Molecular Medicine, 2004. 10(12): p. 585-590.

49. Voutetakis, A., Systemic Delivery of Bioactive Glucagon-Like Peptide 1 after AdenoviralMediated Gene Transfer in the Murine Salivary Gland. Endocrinology, 2010. 151(9): p. 4566-4572.

50. O'Connell, B.C., Transfer of a gene encoding the anticandidal protein histatin 3 to salivary glands. Hum Gene Ther, 1996. 7(18): p. 2255-61.

51. Mullis, P.E., J. Deladoey, and P.S. Dannies, Molecular and cellular basis of isolated dominant-negative growth hormone deficiency, IGHD type II: insights on the secretory pathway of peptide hormones. Horm Res, 2002. 58(2): p. 53-66.

52. Voutetakis, A., Salivary glands as a potential gene transfer target for gene therapeutics of some monogenetic endocrine disorders. J Endocrinol, 2005. 185(3): p. 363-372.

53. Johnson., Single step purification of polypeptides expressed in Escherichia coli as fusions with glutathione S-transferase. Gene, 1988. 67: p. 31-40.

54. Neel, J.V.F.a.B.G., Solubilization and Purification of Enzymatically Active Glutathione STransferase (pGEX) Fusion Proteins. Ananlytical Biochemistry, 1993. 210: p. 179-187.

55. Melania E. Mercado- Pimentel, N.c.J., and Gabriel O. Aisemberg, Affinity purification of GST fusion proteins for immunohistochemical studies of gene expression. Protein expression and purification, 2002. 26: p. 260-265.

56. Dixon., Eukaryotic Proteins Expressed in Escherichia coli: An improved Thrombin cleavage and Purification procedure of Fusion Proteins with Glutathione S-transferase. Ananlytical Biochemistry, 1990. 192: p. 262-267.

57. Smith, D.B., Expression of an enzymatically active parasite molecule in Escherichia coli: Schistosoma japonicum glutathione S-transferase. Mol Biochem Parasitol, 1988. 27(2-3): p. 249-56. 
58. Rial, D.V. and E.A. Ceccarelli, Removal of DnaK contamination during fusion protein purifications. Protein Expr Purif, 2002. 25(3): p. 503-7.

59. Swamy, N., Vitamin D receptor interacts with DnaK/heat shock protein 70 : identification of DnaK interaction site on vitamin D receptor. Arch Biochem Biophys, 1999. 363(2): p. 219-26.

60. Dowler, S., G. Kular, and D.R. Alessi, Protein Lipid Overlay Assay. Sci. STKE, 2002. 2002(129): p. pl6-.

61. Keller, P.J., The protein composition of rat parotid saliva and secretory granules. Biochim Biophys Acta, 1975. 379(2): p. 562-70.

62. Ball, W.D., L. Mirels, and A.R. Hand, Psp and Smgb: a model for developmental and functional regulation in the rat major salivary glands. Biochem. Soc. Trans., 2003. 31(Pt 4): p. 777-780.

63. Ball, W.D., The B1-Immunoreactive Proteins of the Perinatal Submandibular Gland: Similarity to the Major Parotid Gland Protein, RPSP. Critical Reviews in Oral Biology \& Medicine, 1993. 4(3): p. 517-524.

64. Shaw, P. and U. Schibler, Structure and expression of the parotid secretory protein gene of mouse. J Mol Biol, 1986. 192(3): p. 567-76.

65. Madsen, H.O. and J.P. Hjorth, Molecular cloning of mouse PSP mRNA. Nucleic Acids Res, 1985. 13(1): p. 1-13.

66. Bingle, C.D. and C.J. Craven, Meet the relatives: a family of BPI- and LBP-related proteins. Trends in Immunology, 2004. 25(2): p. 53-55.

67. Bingle, C.D. and C.J. Craven, PLUNC: A novel family of candidate host defence proteins expressed in the upper airways and nasopharynx. Human Molecular Genetics, 2002. 11(8): p. 937-943.

68. Bingle, C.D. and S.U. Gorr, Host defense in oral and airway epithelia: chromosome 20 contributes a new protein family. The International Journal of Biochemistry \& Cell Biology, 2004. 36(11): p. 2144-2152.

69. Bingle, L., Characterisation and expression of SPLUNC2, the human orthologue of rodent parotid secretory protein. Histochemistry and Cell Biology, 2009. 132(3): p. 339-349.

70. Vitorino, R., Identification of human whole saliva protein components using proteomics. Proteomics, 2004. 4(4): p. 1109-1115.

71. Baneyx, F., Recombinant protein expression in Escherichia coli. Curr Opin Biotechnol, 1999. 10(5): p. 411-21.

72. Cabrita, L., W. Dai, and S. Bottomley, A family of E. coli expression vectors for laboratory scale and high throughput soluble protein production. BMC Biotechnology, 2006. 6(1): p. 12.

73. Waugh, D.S., Making the most of affinity tags. Trends in Biotechnology, 2005. 23(6): p. 316-320.

74. Malhotra, A., Chapter 16 Tagging for Protein Expression, in Methods in Enzymology, R.B. Richard and P.D. Murray, Editors. 2009, Academic Press. p. 239-258.

75. Arnau, J., et al., Current strategies for the use of affinity tags and tag removal for the purification of recombinant proteins. Protein expression and purification, 2006. 48(1): p. 1-13.

76. Yeliseev, A., L. Zoubak, and K. Gawrisch, Use of dual affinity tags for expression and purification of functional peripheral cannabinoid receptor. Protein expression and purification, 2007. 53(1): p. 153-163. 
77. Nogi, T., Novel affinity tag system using structurally defined antibody-tag interaction: Application to single-step protein purification. Protein Science, 2008. 17(12): p. 21202126.

78. Ventura, S. and A. Villaverde, Protein quality in bacterial inclusion bodies. Trends in Biotechnology, 2006. 24(4): p. 179-185.

79. Singh, S.M. and A.K. Panda, Solubilization and refolding of bacterial inclusion body proteins. Journal of Bioscience and Bioengineering, 2005. 99(4): p. 303-310.

80. Smith, D., Generationg fusions to glutathione $S$ transferase for protein studies. Methods in Enzymology. 326: p. 254-270.

81. Hesterkamp, T. and B. Bukau, Role of the DnaK and HscA homologs of Hsp70 chaperones in protein folding in E.coli. EMBO J, 1998. 17(16): p. 4818-4828.

82. Birringer, M.S., High-level expression and purification of human thymidine kinase 1: Quaternary structure, stability, and kinetics. Protein expression and purification, 2006. 47(2): p. 506-515.

83. Bukau, B. and A.L. Horwich, The Hsp70 and Hsp60 Chaperone Machines. Cell, 1998. 92(3): p. 351-366.

84. Arvan, P., G. Rudnick, and J.D. Castle, Osmotic properties and internal pH of isolated rat parotid secretory granules. Journal of Biological Chemistry, 1984. 259(21): p. 1356713572.

85. Stahelin, R.V., Membrane Binding Mechanisms of the PX Domains of NADPH Oxidase p40phox and p47phox. Journal of Biological Chemistry, 2003. 278(16): p. 14469-14479.

86. Vanhaesebroeck, B., SYNTHESIS AND FUNCTION OF 3-PHOSPHORYLATED INOSITOL LIPIDS. Annual Review of Biochemistry, 2001. 70(1): p. 535-602.

87. Franke, T.F., et al., Direct Regulation of the Akt Proto-Oncogene Product by Phosphatidylinositol-3,4-bisphosphate. Science, 1997. 275(5300): p. 665-668.

88. Pawelczyk, T. and A. Matecki, Phospholipase $C-\delta 3$ binds with high specificity to phosphatidylinositol 4,5-bisphosphate and phosphatidic acid in bilayer membranes. European Journal of Biochemistry, 1999. 262(2): p. 291-298.

89. Cozier, G.E., D. Bouyoucef, and P.J. Cullen, Engineering the phosphoinositide-binding profile of a class I pleckstrin homology domain. J Biol Chem, 2003. 278(41): p. 39489-96.

90. He, J., et al., Molecular mechanism of membrane targeting by the GRP1 PH domain. Journal of Lipid Research, 2008. 49(8): p. 1807-1815.

91. Klein, D.E., The Pleckstrin Homology Domains of Dynamin Isoforms Require Oligomerization for High Affinity Phosphoinositide Binding. J. Biol. Chem., 1998.273(42): p. 27725-27733.

92. Manna, D., Mechanistic Basis of Differential Cellular Responses of Phosphatidylinositol 3,4-Bisphosphate- and Phosphatidylinositol 3,4,5-Trisphosphate-binding Pleckstrin Homology Domains. Journal of Biological Chemistry, 2007. 282(44): p. 32093-32105. 


\section{CURRICULUM VITAE}

NAME: $\quad$ Dipti Goyal

ADDRESS: $\quad$ B-5/188 Safdarjung Enclave

New Delhi, India-110029

$(+91)-11-26196747$

DOB: $\quad 14$ Dec, 1984

\section{EDUCATION}

- Bachelors in Dental Surgery, Government Dental College, Rohtak, India. July 2002 July 2007

\section{RESEARCH PROJECTS AND HONORS}

- Recipient of Graduate Dean's Citation Award, UofL, 2010.

- Oral presentation, AADR Annual Meeting, April 2009.

TITLE: "Binding of Parotid Secretory protein to Membrane Phosphatidylinositol Bisphosphate" by S. Venkatesh, A. Carenbauer, D. Goyal, D. Darling.

- Poster presentation, Graduate Research Symposium, UofL, Feb 2009.

TITLE: "Direct Binding of Affinity Purified PSP with Phophatidylinositol Phosphates" by D.Goyal, A.Carenbauer, D.Darling

- Poster presentation, Research Louisville, UofL, Oct 2008. ${ }^{\text {st }}$ prize TITLE: "Direct Binding of Affinity Purified rPSP with Phosphatidylinositol Phosphates" by D. Goyal, A. Carenbauer, D. Darling

- Summer Research Fellowship, Dental School, UofL. May 2008 - Aug 2008.

TITLE: "Direct Binding of Affinity Purified PSP with Phophatidylinositol Phosphates" 